\title{
ADVANCES IN LOW COST SILVER-CONTAINING THICK FILM CONDUCTORS
}

\author{
BARRY E. TAYLOR, JOHN J. FELTEN, SAMUEL J. HOROWITZ, JOHN R. LARRY and \\ RICHARD M. ROSENBERG \\ E. I. du Pont de Nemours \& Company, Inc., Electronic Materials Division, Photo Products Department, \\ Niagara Falls, New York 14302
}

\begin{abstract}
Extensive use of thick film materials to manufacture resistor networks and hybrid integrated circuits has come about because of economic, processing and functional advantages over other technologies in the high volume production of miniaturized circuits. Inherent in the adoption of thick film technology for increasingly diverse applications has been the ability of thick film material suppliers to provide progressive performance improvements at lower cost concurrent with circuit manufacturer's needs. Since the first major commercial thick film adoption in the early sixties, when IBM adopted platinum gold conductors and palladium silver resistors in their 360 computers, rapid technological advances over the last decade have produced an increasing variety of hybrid circuits and networks. The wide adoption of thick film technology in all segments of the electronic industry has placed increasing demands on performance and processing latitude. This paper outlines the development of low cost silver-bearing conductors and describes the evolution of technology improvements to present day systems. The initial segment reviews the deficiencies of early $\mathrm{Pd} / \mathrm{Ag}$ conductors, particularly solder leach resistance and degradation of soldered adhesion following high temperature storage, and focuses on the first $\mathrm{Pd} / \mathrm{Ag}$ system which overcame these problems. Extension of this technology and subsequent improvements in both binders and vehicles to fulfill adhesion requirements to $\mathrm{Al}_{2} \mathrm{O}_{3}$ substrates of varying chemistries and to meet demands for high speed printing are also described. The second segment gives an overview of the present understanding of thick film conductor composites from a mechanistic point of view. The various types of binder systems commonly employed in conductors are discussed in terms of how they effect a bond between the sintered metal and the substrate, and the advantages and disadvantages of each type. Metallurgical aspects of conductor/solder connections are considered and their effects on bond reliability following exposure to high temperature discussed. Rheological considerations of paste design are presented and related to printing performance. The final segment focuses on newer low cost, high performance material systems that have evolved over the past two years. The technologies of each system are reviewed in terms of metallurgy, binder and vehicle. Important functional properties are presented to illustrate cost/performance tradeoffs. Special emphasis is given to recently developed high $\mathrm{Ag}$ containing conductors which have outstanding soldered adhesion even after 1000 hours of storage at $150^{\circ} \mathrm{C}$.
\end{abstract}

\section{INTRODUCTION}

Thick film conductors are composed of three functional materials: metal powders which serve as the conductive phase, glasses or oxides which promote sintering of the metal powders during firing and bind the metal film to the substrate, and organic phases which disperse the metal and binder components to provide the desired rheological properties. Each of these materials is extremely important in determining the performance and reliability of the fired thick film.

Conductor compositions for initial microcircuit applications were based on $\mathrm{Pt} / \mathrm{Au}$ and $\mathrm{Pd} / \mathrm{Au}$ metallurgies to insure long term reliability. These compositions provided exceptional solder leach resistance in $\mathrm{Sn} / \mathrm{Pb}$ solders, had good adhesion and eliminated any concerns of silver migration. As the technology expanded into cost-sensitive less demanding consumer applications, $\mathrm{Pd} / \mathrm{Ag}$ metallurgies were adopted. Although these early $\mathrm{Pd} / \mathrm{Ag}$ conductors provided lower cost alternatives to $\mathrm{Pt} / \mathrm{Au}$ and $\mathrm{Pd} / \mathrm{Au}$ systems, adhesion of the soldered conductor decreased significantly after storage at temperatures of $125^{\circ} \mathrm{C}$ or higher. An understanding of the failure mechanism has been the goal of various studies over the past decade.

The most widely accepted hypothesis proposed by Crossland and Hailes, ${ }^{1}$ attributes failure to interdiffusion of solder and conductor metals with attendant formation of intermetallics such as $\mathrm{PdSn}_{3}$. Subsequently, $\mathrm{Ag}_{3} \mathrm{Sn}$ and $\mathrm{Ag}_{5} \mathrm{Sn}$ were also identified. ${ }^{2}$ Volume changes associated with intermetallic formation weaken the glass network within the sintered 
metal and disrupt the bond between conductor and substrate.

This model provides a reasonable explanation for adhesion degradation after thermal storage, but fails to answer several questions. For example, why does adhesion continue to gradually degrade after swelling is apparently complete? Crossland and Hailes ${ }^{1}$ observed a threefold increase in the conductor layer thickness which they ascribed to intermetallic formation. Although the swelling occurs in a period of several hours at temperatures of $125^{\circ} \mathrm{C}$ or higher, adhesion continues to degrade even "after the intermetallic has apparently formed right down to the conductor/glaze interface." They conclude that "the reason for this must be related to the precise nature of the bonding mechansim. It may be that the attack of the Sn on the bonding layer is slower because of the complexity of the bonding mechanism, i.e., oxides may be involved." Another problem with the above model is that it fails to explain why many conductors exhibit two to threefold volume increases after aging of soldered parts, but do not show any significant adhesion degradation.

Ewell, ${ }^{3}$ in discussing aged adhesion degradation of $\mathrm{Au}-\mathrm{Pt}-\mathrm{Pd}$ terminations, states that the microstructure "show(s) large fractions of the as-fired surfaces of frit-bonded Au metallizations covered by glass phases. The process of adhesion loss must then involve $\mathrm{Sn}$ mobility along the glass and metal surface phases, diffusion through the glass phase (possibly) and formation of intermetallic compounds whose increased specific volume results in gradual fracture of the glass bonds thought to provide mechanical interlocking with the alumina substrate."

Milgram $^{4}$ also observed adhesion degradation of silver films after thermal storage and attributed the loss in adhesion to replacement of the silver at the glass (substrate) boundary by tin. He also showed that the rate of degradation due to grain boundary diffusion was related to the porosity of the thick film.

It is clear from the foregoing discussion that the mechanism responsible for degradation of adhesion is not fully understood. A portion of this paper will explore this phenomenon further and evidence will be presented which suggests that intermetallic formation is not the primary failure mechanism.

Although improvement in conductor adhesion has received the most attention and publicity during the past decade, other important properties such as solderability, silver migration resistance, ${ }^{5}$ solder leach resistance and wire bondability have also been emphasized. This will become apparent as lower cost conductor developments are traced historically and their performance attributes and tradeoffs described.

\section{EXPERIMENTAL}

\subsection{Preparation of Fired Films}

Conductor compositions were screen printed onto alumina (96\%) substrates using an automatic screen printer and a 200 mesh stainless steel screen with a $12.5 \mu$ emulsion. Dried film thicknesses were generally $25 \mu$ unless otherwise reported. The test pattern consisted of nine $2 \mathrm{~mm} \times 2 \mathrm{~mm}$ pads used for adhesion and a serpentine line, $0.5 \mathrm{~mm} \times 100 \mathrm{~mm}(200 \square)$, for measuring resistivity. After drying at $150^{\circ} \mathrm{C}$ for $10-15$ minutes, the test parts were fired on a belt furnace at a peak temperature of $850^{\circ} \mathrm{C}$, with a peak dwell time of 10 minutes. Conductor test parts were fired from one to five times to test variability of properties with repeated firings.

\subsection{Solderability Tests}

Solderability was assessed by dipping the fired conductor for 5 seconds in $62 \mathrm{Sn} / 36 \mathrm{~Pb} / 2 \mathrm{Ag}$ and 63 $\mathrm{Sn} / 37 \mathrm{~Pb}$ solders at 220 and $235^{\circ} \mathrm{C}$, respectively, and observing the extent of coverage. A mildly activated flux such as Alpha 611 was used. Tests were also conducted at other temperatures to determine the overall processing latitude. Solder leach resistance was determined by dipping fired conductor films in 62 $\mathrm{Sn} / 36 \mathrm{~Pb} / 2 \mathrm{Ag}$ solder at $230^{\circ} \mathrm{C}$ and $63 \mathrm{Sn} / 37 \mathrm{~Pb}$ solder at $250^{\circ} \mathrm{C}$. Solder spread tests were also carried out to obtain a semi-quantitative assessment of solderability.

\subsection{Adhesion Studies}

Peel adhesion performance was determined by the following procedure. Twenty gauge pre-tinned copper wires were attached to $2 \mathrm{~mm} \times 2 \mathrm{~mm}$ pads by solder dipping for 10 seconds in $62 \mathrm{Sn} / 36 \mathrm{~Pb} / 2 \mathrm{Ag}$ solder at $220^{\circ} \mathrm{C}$ or in $63 \mathrm{Sn} / 37 \mathrm{~Pb}$ solder at $230^{\circ} \mathrm{C}$ using Alpha 611 flux. Test parts were aged at $150^{\circ} \mathrm{C}$ in a Blue $\mathrm{M}$ Stabil Therm ${ }^{\circledR}$ oven. After aging, test parts were allowed to equilibrate several hours in air before the wires were pulled with an "Instron" pull tester in a $90^{\circ} \mathrm{C}$ peel configuration.

\subsection{Scanning Electron Microscopy Studies}

Scanning Electron Microscopy of polished cross-sections was used to determine the nature of the metal-binder-substrate interaction in the fired conductor films. Through use of Energy Dispersive Analysis of X-rays (EDAX), individual elements of the 
solder-metal-binder composite were mapped and the relative concentrations of each component as a function of thermal aging time were determined. Aging times varied from 0 to 1000 hours.

\subsection{Wire Bonding Studies}

Limited ultrasonic $\mathrm{Al}$ and thermosonic Au wire bonding studies were carried out on several of the thick film conductors discussed below. Parts for ultrasonic bonding were fired five times at $850^{\circ} \mathrm{C}$ and once at $500^{\circ} \mathrm{C}$ to simulate an encapsulation cycle. A Model 484 $\mathrm{K} \& \mathrm{~S}$ bonder, equipped with a titanium carbide tool, was used with a 1 mil $\mathrm{Al}(1 \% \mathrm{Si}), 2.1 \%$ elongation wire. The bond power was 0.02 watts and the bond time was 32-38 milliseconds for the first bond and 30-32 milliseconds for the second bond.

Parts for thermosonic gold wire bonding were fired one and five times at $850^{\circ} \mathrm{C}$. In one set of experiments parts were fired five times at $850^{\circ} \mathrm{C}$ and once at $500^{\circ} \mathrm{C}$. A Model $479 \mathrm{~K} \& S$ bonder was used with 1 mil gold wire (5-8\% elongation) and a ceramic tool with a tool force of 45-50 grams for the first bond and 110-115 g. for the second bond. Wire bond adhesion was determined after exposure to $150^{\circ} \mathrm{C}$ and $200^{\circ} \mathrm{C}$ for times up to 1000 hours.

\section{DISCUSSION}

Table I lists several silver-bearing conductors in chronological order of development. The early 8151 $\mathrm{Pd} / \mathrm{Ag}$ conductor offered a low cost alternative to $\mathrm{Pt} / \mathrm{Au}$ and $\mathrm{Pd} / \mathrm{Au}$ metallurgies. However, the adhesion of this conductor after soldering with $62 \mathrm{Sn} / 36 \mathrm{~Pb} / 2 \mathrm{Ag}$ or $63 \mathrm{Sn} / 37 \mathrm{~Pb}$ degraded significantly following a brief exposure of a few hours at $150^{\circ} \mathrm{C}$ and levelled off between 200 and 500 hours. Figure 1 illustrates this behaviour Crossland et al ${ }^{1}$ reported similar results and noted that the adhesion of 8151 was dependent on solder type $(60 \mathrm{Sn} / 40 \mathrm{~Pb}$ worse than $75 \mathrm{~Pb} / 25 \mathrm{Cd})$, firing temperature and substrate-type.

Scanning electron microscopy of conductor cross-sections (Figure 2) shows that the soldered conductor film undergoes a two-to-threefold volume increase after it has been aged for 26 hours. However, no further swelling is observed through 500 hours. Elemental mapping with EDAX, shown in Figure 3, clearly shows that a lead-rich and tin-deficient region begins to develop at the solder-conductor interface after 48 hours at $150^{\circ} \mathrm{C}$ and is well established after 500 hours. The creation of this region is believed to be due to the different diffusion rates of lead and tin into
TABLE I

Chronology of low cost conductor development.

\begin{tabular}{|c|c|c|c|}
\hline Conductor & $\begin{array}{l}\text { Date of } \\
\text { Intro- } \\
\text { duction }\end{array}$ & $\mathrm{Ag} / \mathrm{Pd}$ Ratio & Reason for Development \\
\hline 8151 & 1969 & $2 / 1$ & $\begin{array}{l}\text { Low Cost Alternative to } \\
\text { Pt/Au Conductors }\end{array}$ \\
\hline 9061 & 1972 & $2.5 / 1$ & Improved Aged Adhesion \\
\hline 9071 & 1972 & $6 / 1$ & $\begin{array}{l}\text { Good Adhesion on Different } \\
\text { Substrates }\end{array}$ \\
\hline 9473 & 1974 & $3 / 1$ & $\begin{array}{l}\text { Lower Cost, Good Adhesion } \\
\text { on Different Substrates }\end{array}$ \\
\hline 9770 & 1975 & $(\mathrm{Ag} / \mathrm{Pt})$ & $\begin{array}{l}\text { Excellent Solderability. } \\
\text { Low Cost }\end{array}$ \\
\hline 9755 & 1975 & $\begin{array}{l}\text { Ternary } \\
\left(\mathrm{Ag} / \mathrm{Pd} / \mathrm{P}^{*}\right)\end{array}$ & $\begin{array}{l}\text { Good Silver Migration Resistance } \\
\text { and Solder Leach Resistance }\end{array}$ \\
\hline 9843 & 1976 & $2.5 / 1$ & $\begin{array}{l}\text { Sprint " Modified } 9061 \text { for } \\
\text { High Speed Printing }\end{array}$ \\
\hline 6120 & 1977 & $2.5 / 1$ & $\begin{array}{l}\text { Improved Coverage and Aged } \\
\text { Adhesion }\end{array}$ \\
\hline 6130 & 1977 & $6 / 1$ & $\begin{array}{l}\text { Good Solder Acceptance and } \\
\text { Aged Adhesion }\end{array}$ \\
\hline 4093 & 1978 & $\begin{array}{l}\text { Ternary } \\
(\mathrm{Ag} / \mathrm{Pd} / \mathrm{Pt})\end{array}$ & $\begin{array}{l}\text { Excellent Silver Migration } \\
\text { Resistance. Good Solder } \\
\text { Leach Resistance }\end{array}$ \\
\hline 6160 & 1979 & $\mathrm{Ag}$ & $\begin{array}{l}\text { Excellent Aged Adhesion and } \\
\text { Solderability }\end{array}$ \\
\hline
\end{tabular}

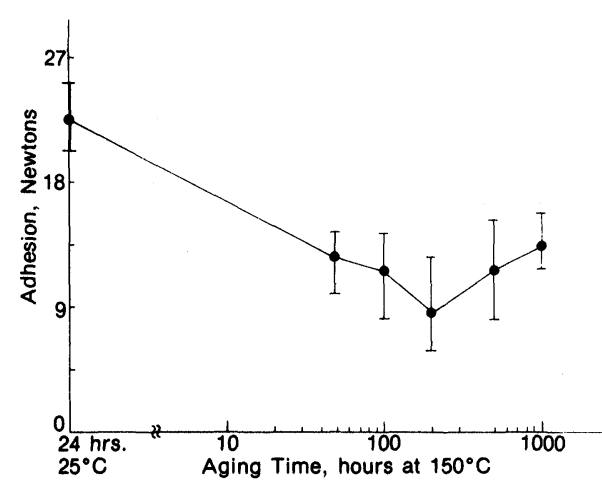

FIGURE 1 Aged adhesion vs. aging time for $8151 \mathrm{Pd} / \mathrm{Ag}$.

the conductor film. Since tin diffuses much faster, it leaves a tin-deficient region behind. Several of the conductors discussed below exhibit the lead-rich, tin-deficient layer after thermal aging. In their work with $\mathrm{Pd} / \mathrm{Au}$ conductor, 8227, Crossland et al ${ }^{1}$ observed a similar region. Once established, this lead-rich region probably acts as a barrier layer to retard further diffusion of tin into the conductor film.

Although 8151 was a good state-of-the-art $\mathrm{Pd} / \mathrm{Ag}$ conductor and satisfied several industrial needs in this early stage of low cost silver-bearing conductor technology, a new $\mathrm{Pd} / \mathrm{Ag}$ conductor with improved 


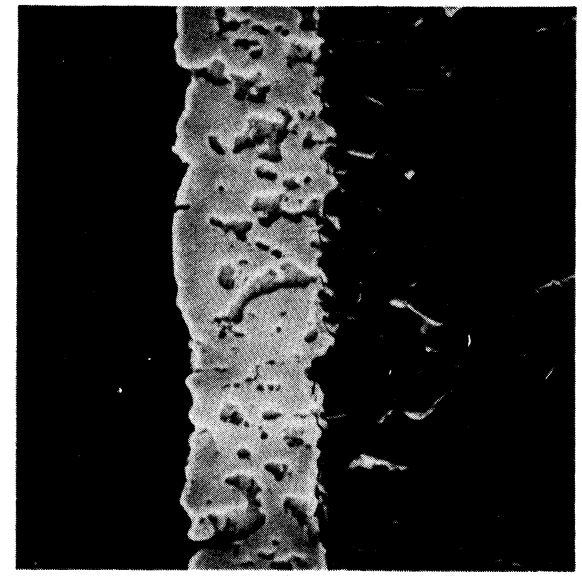

Unsoldered

$1500 x$

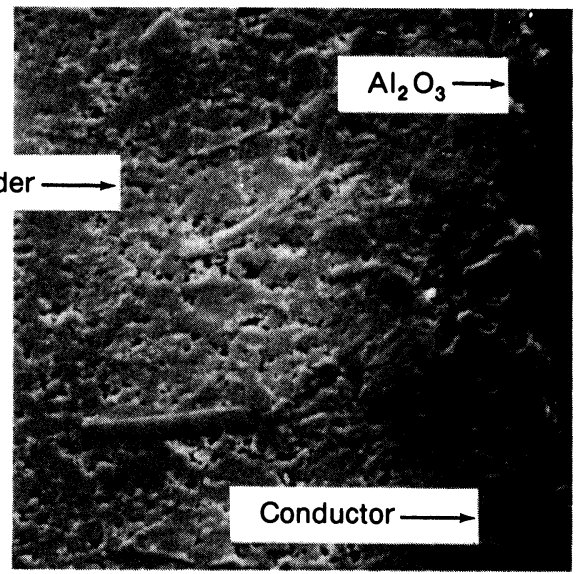

Aged $8 \mathrm{hrs}$. at $150^{\circ} \mathrm{C}$

$1500 x$

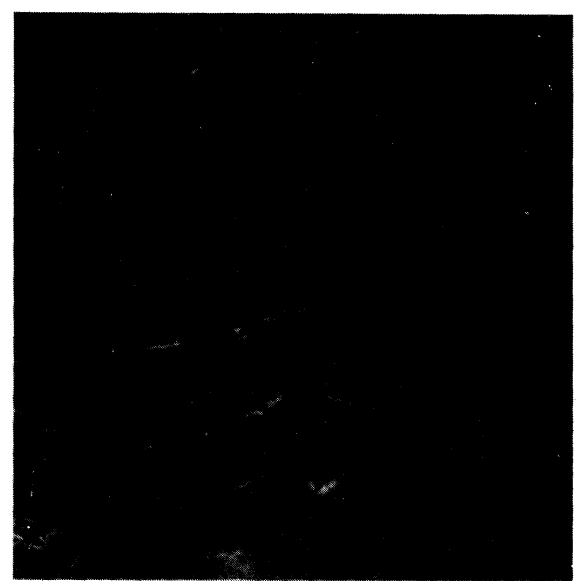

Aged $48 \mathrm{hrs}$. at $150^{\circ} \mathrm{C}$

$1200 x$

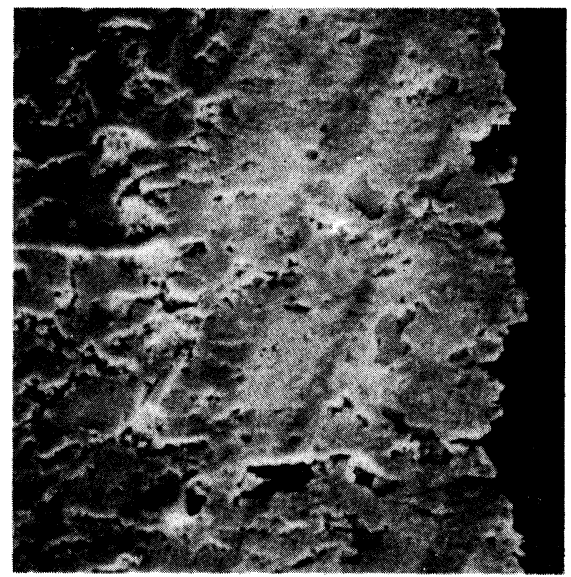

Soldered, unaged

$1500 x$

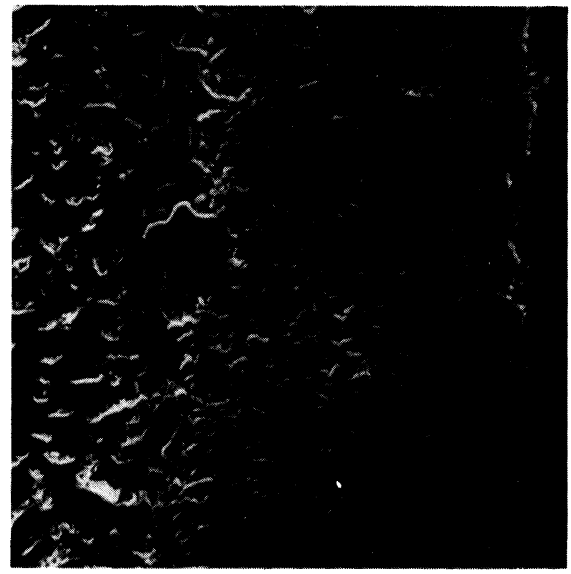

Aged $26 \mathrm{hrs}$. at $150^{\circ} \mathrm{C}$

$1500 x$

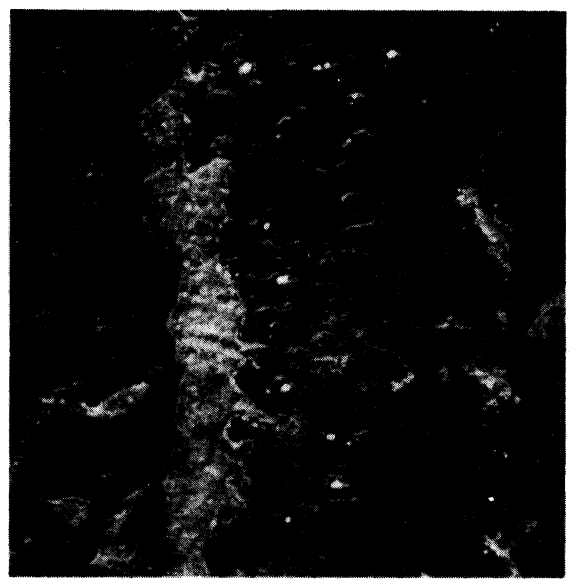

Aged $500 \mathrm{hrs}$. at $150^{\circ} \mathrm{C}$

FIGURE 2 Cross-sections of $8151 \mathrm{Pd} / \mathrm{Ag}$ - soldered conductor thickness vs. aging time. 

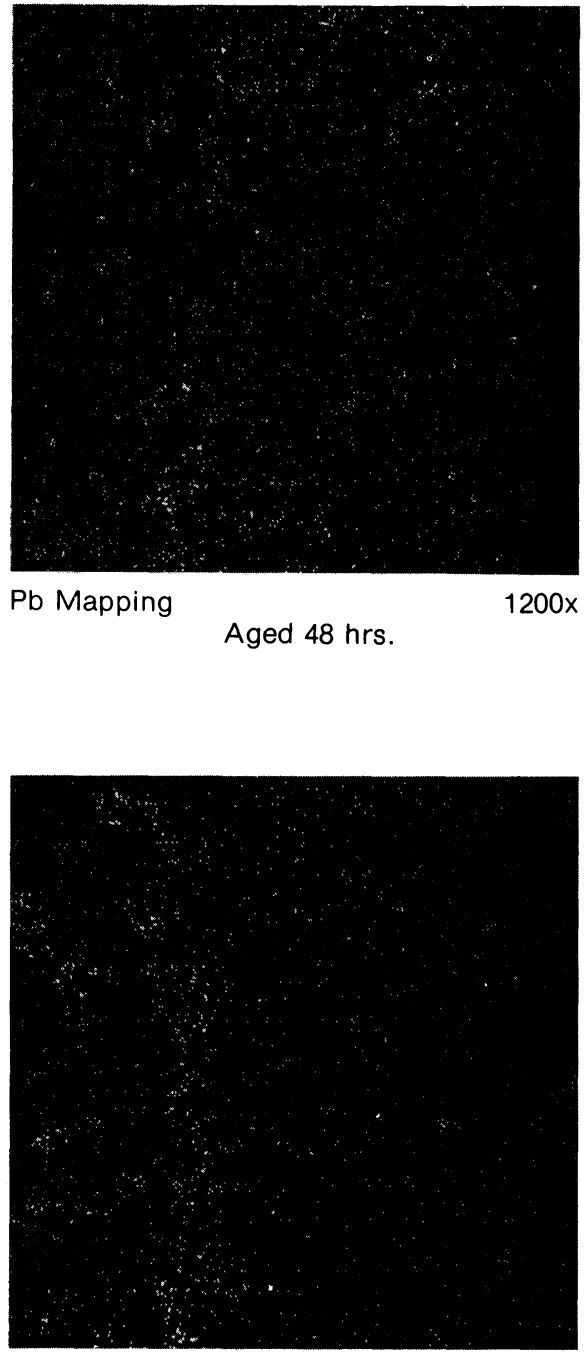

$\mathrm{Pb}$ Mapping

$1200 x$

Aged 500 hrs

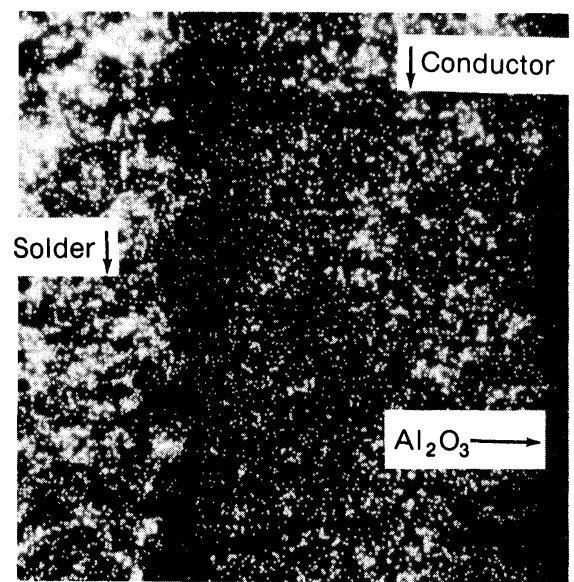

Sn Mapping

Aged 48 hrs

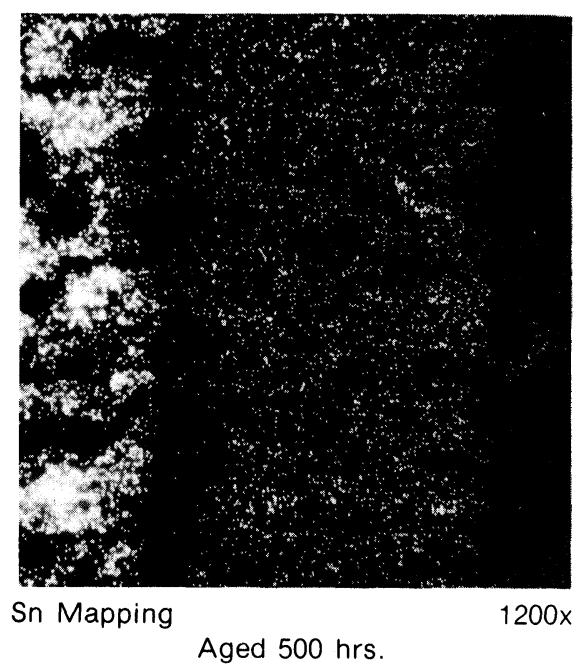

FIGURE 3 Elemental mapping of $8151 \mathrm{Pd} / \mathrm{Ag}$ for lead and tin.

adhesion properties and better solder leach resistance was needed. The development of a conductor with these improvements depended upon enhanced conductor film density and better binder efficiency obtained through new technology for making both metal powders and binders.

These improvements were incorporated into 9061, a general purpose $\mathrm{Pd} / \mathrm{Ag}$ conductor which was introduced in 1972 and is still widely used today. This composition was the first $\mathrm{Pd} / \mathrm{Ag}$ conductor which largely circumvented the problem of aged adhesion degradation. Adhesion tests reveal that 9061 has excellent adhesion after thermal storage at $150^{\circ} \mathrm{C}$ through 1000 hours. Figure 4 illustrates the effect of aging at $150^{\circ} \mathrm{C}$ on adhesion for parts using $63 \mathrm{Sn} / 37 \mathrm{~Pb}$ and $62 \mathrm{Sn} / 36 \mathrm{~Pb} / 2 \mathrm{Ag}$ solders. Essentially equivalent results are obtained for the two types of solder. Scanning electron micrographs (Figure 5) show that the conductor swells to more than twice its as-fired thickness after aging only 8 hours at $150^{\circ} \mathrm{C}$, similar to 8151. However, in the case of 9061 no significant degradation in aged adhesion is observed. Since the apparent volume expansion for both conductors is similar, this suggests that swelling, due to tin diffusion 


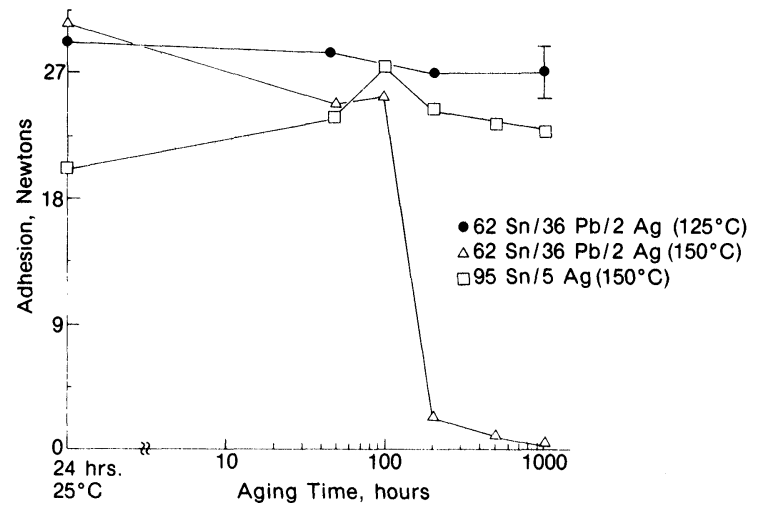

FIGURE 4 Aged adhesion vs. aging time and temperature for $9770 \mathrm{Pt} / \mathrm{Ag}$.

into the conductor film, may not be the sole cause of adhesion degradation of 8151 .

It is difficult to determine unambiguously whether the observed adhesion differences are due to mechanical phenomena (swelling with subsequent weakening of the substrate-glass-metal bond) or to chemical processes occurring between the various thick film components since the binder chemistry of the two conductors is different.

Although 9061 gave excellent soldered aged adhesion on many widely used $96 \%$ alumina substrates having magnesia-based binders, performance on substrates with different binder chemistry, particularly several produced in Europe, was less satisfactory. When the European microelectronics industry began a period of rapid growth about 1972, it became obvious that thick film conductors were needed which would be less sensitive to small variations in substrate chemistry. Two conductors developed in late 1972 and early 1974 were designed to minimize this problem and give high adhesion values on alumina substrates of different chemical composition. The improved process latitude was a consequence of new binder chemistry to give a more"reactive" metal-ceramic seal. Adhesion data and microscopic analysis for one such conductor (9071) has been reported by Larry and Amin. ${ }^{6}$ They were able to show a marked improvement in aged adhesion values with additions of polynary oxides to conventional glass bonded conductors. (The combination of a glass plus inorganic oxide is commonly referred to as a "mixed binder.") Electron microprobe scans of soldered conductor films which have been cross-sectioned reveal that most of the polynary oxide additive is concentrated between the silver-palladium film and the alumina substrate. Furthermore, the oxide additive appears to penetrate the substrate to a depth of $\sim 40 \mu$. Some of the oxide additive also reacts with the glass binder thereby improving its mechanical strength. This enhanced reactivity with alumina and the glass binder and the attendant strengthening in the conductor film composite is believed responsible for the high adhesion values obtained for substrates of slightly different chemical composition.

Further binder modifications led to the development of $9473 \mathrm{Pd} / \mathrm{Ag}$, mixed bonded conductor still widely used in Europe. The high adhesion obtained on substrates of different chemical type, designated "European Substrate A" and "European Substrate B" in Table II, is a result of the highly reactive binder system. Adhesion of 9061 on "European Substrate B" is shown for comparison.

Du Pont's first chemically bonded silver-bearing conductor $(9770 \mathrm{Pt} / \mathrm{Ag})$ was introduced in 1975 . This conductor demonstrates excellent solderability and good solder leach resistance in low temperature solders and is ideally suited for cost-sensitive applications. Compared to typical glass bonded conductors, 9770 has high conductivity and sinters to a dense non-porous film when fired at $850^{\circ} \mathrm{C}$ because of its high silver content and low binder level.

The aged adhesion of 9770 as shown in Figure 6 is strongly dependent on solder type and aging conditions. Parts soldered with $62 \mathrm{Sn} / 36 \mathrm{~Pb} / 2 \mathrm{Ag}$ solder and aged at $125^{\circ} \mathrm{C}$ show little adhesion degradation well past 1000 hours, whereas parts aged at $150^{\circ} \mathrm{C}$ show a sharp decline in adhesion after about 200 hours. Parts soldered with $95 \mathrm{Sn} / 5 \mathrm{Ag}$ and aged at $150^{\circ} \mathrm{C}$ exhibit little adhesion degradation through 1000

TABLE II

Aged adhesion of $9473 \mathrm{Pd} / \mathrm{Ag}$ on different substrates.

\begin{tabular}{|c|c|c|}
\hline \multirow[b]{2}{*}{$\begin{array}{l}\text { ALSIMAG } 614 \\
\left(96 \% \mathrm{Al}_{2} \mathrm{O}_{3}\right) \\
\end{array}$} & \multicolumn{2}{|c|}{ Adhesion in Newtons } \\
\hline & $\frac{62 \mathrm{Sn} / 36 \mathrm{~Pb} / 2 \mathrm{Ag}}{\left(48 \mathrm{Hrs} / 150^{\circ} \mathrm{C}\right)}$ & $\frac{63 \mathrm{Sn} / 37 \mathrm{~Pb}}{\left(48 \mathrm{Hrs} / 150^{\circ} \mathrm{C}\right)}$ \\
\hline $1 \times 850^{\circ} \mathrm{C}$ & 24 & 25 \\
\hline \multicolumn{3}{|l|}{$\begin{array}{l}\text { European Substrate A } \\
\left(92 \% \mathrm{Al}_{2} \mathrm{O}_{3}\right) \\
\end{array}$} \\
\hline $1 \times 850^{\circ} \mathrm{C}$ & 23 & 26 \\
\hline$+\left\{\begin{array}{l}3 \times 850^{\circ} \mathrm{C} \\
1 \times 500^{\circ} \mathrm{C}\end{array}\right.$ & 27 & 29 \\
\hline \multicolumn{3}{|l|}{$\begin{array}{l}\text { European Substrate B } \\
\left(96 \% \mathrm{Al}_{2} \mathrm{O}_{3}\right) \\
\end{array}$} \\
\hline $1 \times 850^{\circ} \mathrm{C}$ & 23 & 25 \\
\hline$+\left\{\begin{array}{l}3 \times 850^{\circ} \mathrm{C} \\
1 \times 500^{\circ} \mathrm{C}\end{array}\right.$ & 26 & 27 \\
\hline$\frac{9061 \text { on Europear }}{1 \times 850^{\circ} \mathrm{C}}$ & trate B 12 & 13 \\
\hline
\end{tabular}



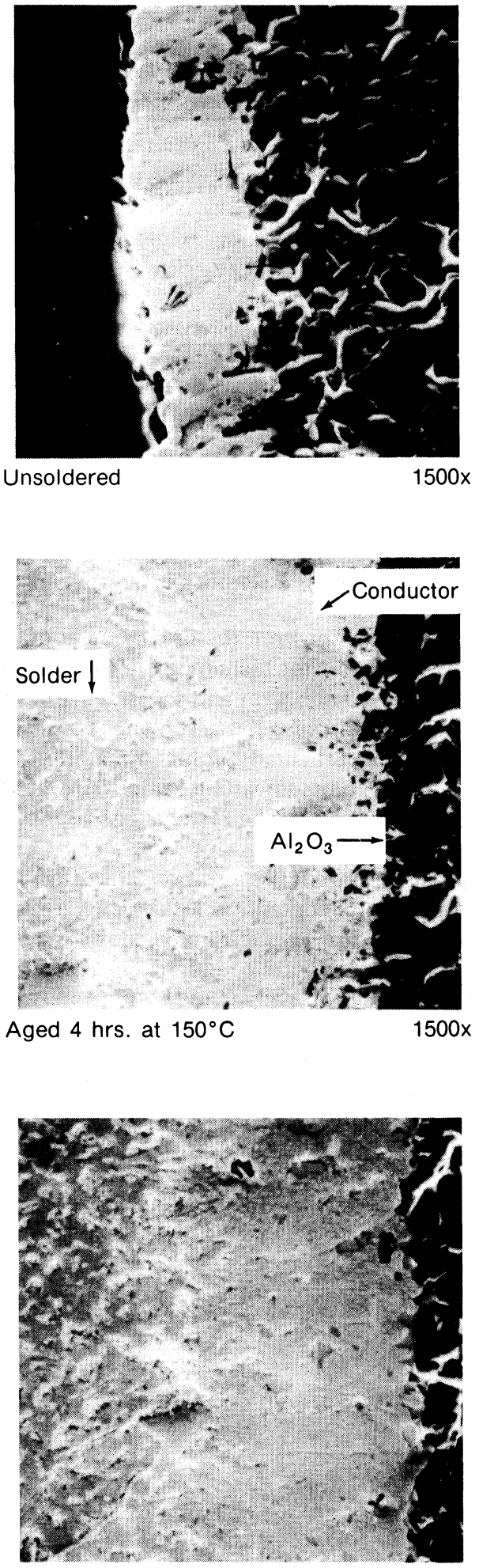

Aged $16 \mathrm{hrs}$. at $150^{\circ} \mathrm{C}$
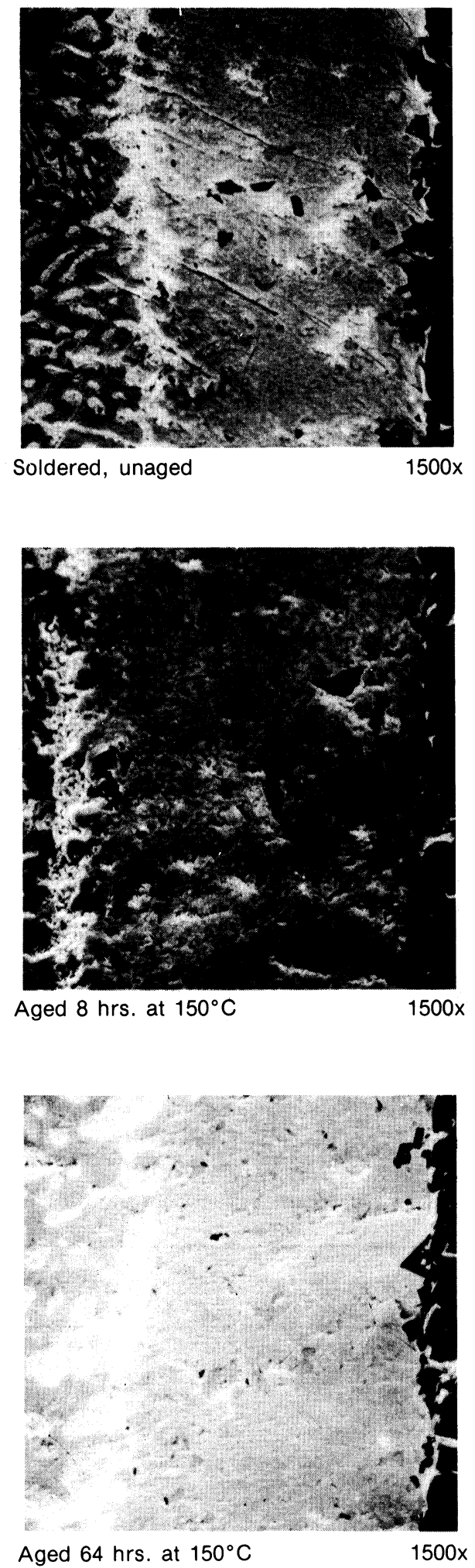

$1500 x$

FIGURE 5 Cross-sections of $9061 \mathrm{Pd} / \mathrm{Ag}$ - soldered conductor thickness vs. aging time. 


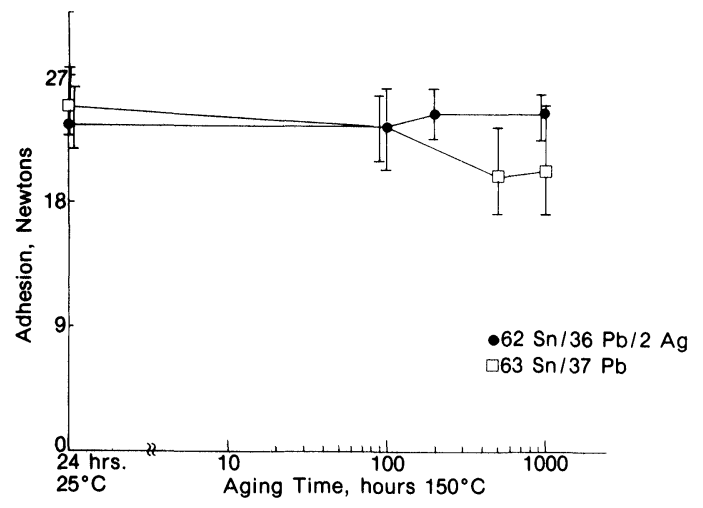

FIGURE 6 Aged adhesion vs. aging time for $9061 \mathrm{Pd} / \mathrm{Ag}$.

hours. The improved adhesion with $95 \mathrm{Sn} / 5 \mathrm{Ag}$ solder over $62 \mathrm{Sn} / 36 \mathrm{~Pb} / 2 \mathrm{Ag}$ is indicative of a tin diffusion-related phenomenon. The aging temperature of $150^{\circ} \mathrm{C}$ is only $30^{\circ} \mathrm{C}$ below the liquidus temperature of $62 \mathrm{Sn} / 36 \mathrm{~Pb} / 2 \mathrm{Ag}$ solder whereas it is about $100^{\circ} \mathrm{C}$ below the liquidus of $95 \mathrm{Sn} / 5 \mathrm{Ag}$ solder. Therefore, the diffusion rate of tin in the $95 \mathrm{Sn} / 5 \mathrm{Ag}$ solder would be slower, and less penetration of tin into the conductor film would occur. Since less tin penetration occurs, adhesion after thermal aging remains high.

A comparison of the solder leach resistance data for the five conductors discussed thus far is presented in Table III. Solder leach resistance is recorded as the number of 10 second dips necessary to leach away half the width of a 20 mil conductor line. The solder leach resistance of 9061 is the best of the group; 9071, 9473 and 9770 also offer a significant improvement over the early 8151 conductor. The enhanced solder leach resistance of these later conductors is due to improved

TABLE III

Comparison of solder leach resistance for silver-bearing conductors.

\begin{tabular}{clcc}
\hline $\begin{array}{c}\text { Conductor } \\
\text { Code }\end{array}$ & \multicolumn{1}{c}{ Solder Type } & $\begin{array}{c}\text { No. of 10 } \\
\text { Second Dips } \\
\text { To Failure }\end{array}$ & $\begin{array}{c}\text { Solder } \\
\text { Temperature } \\
\left({ }^{\circ} \mathrm{C}\right)\end{array}$ \\
\hline \multirow{2}{*}{8151} & $62 \mathrm{Sn} / 36 \mathrm{~Pb} / 2 \mathrm{Ag}$ & 5 & 230 \\
9061 & $62 \mathrm{Sn} / 36 \mathrm{~Pb} / 2 \mathrm{Ag}$ & 10 & 230 \\
& $63 \mathrm{Sn} / 37 \mathrm{~Pb}$ & 6 & 250 \\
& $96 \mathrm{Sn} / 4 \mathrm{Ag}$ & 3 & 260 \\
9071 & $10 \mathrm{Sn} / 90 \mathrm{~Pb}$ & 10 & 330 \\
& $62 \mathrm{Sn} / 36 \mathrm{~Pb} / 2 \mathrm{Ag}$ & 10 & 230 \\
9473 & $63 \mathrm{Sn} / 37 \mathrm{~Pb}$ & 4 & 250 \\
& $62 \mathrm{Sn} / 36 \mathrm{~Pb} / 2 \mathrm{Ag}$ & 8 & 230 \\
9770 & $63 \mathrm{Sn} / 37 \mathrm{~Pb}$ & 4 & 250 \\
& $62 \mathrm{Sn} / 36 \mathrm{~Pb} / 2 \mathrm{Ag}$ & 8 & 250 \\
& $63 \mathrm{Sn} / 37 \mathrm{~Pb}$ & 3 & 270 \\
& $96 \mathrm{Sn} / 4 \mathrm{Ag}$ & 4 & 330 \\
\hline
\end{tabular}

TABLE IV

Adhesion results for silver-bearing conductors.

\begin{tabular}{ccccccc}
\hline & \multicolumn{5}{c}{ Adhesion, Newtons (minimum) } \\
\cline { 3 - 8 } Conductor Code & $\begin{array}{c}\text { Initial } \\
\text { (24 Hrs., RT) }\end{array}$ & $\begin{array}{c}48 \text { Hour } \\
\left(150^{\circ} \mathrm{C}\right)\end{array}$ & $\begin{array}{c}100 \mathrm{Hour} \\
\left(150^{\circ} \mathrm{C}\right)\end{array}$ \\
\hline \multirow{2}{*}{8151} & 22 & $(20)$ & 12 & $(9)$ & 11 & $(8)$ \\
9061 & 24 & $(21)$ & 24 & $(21)$ & 23 & $(20)$ \\
9071 & 21 & $(17)$ & 15 & $(13)$ & 18 & $(15)$ \\
9473 & 26 & $(23)$ & 24 & $(21)$ & 23 & $(21)$ \\
9770 & 24 & $(20)$ & 22 & $(20)$ & 18 & $(15)$ \\
\hline
\end{tabular}

chemical durability of the metallurgy and inorganic binder components.

Table IV compares aged adhesion data for these conductors with $62 \mathrm{Sn} / 36 \mathrm{~Pb} / 2 \mathrm{Ag}$ solder. Best overall performance is shown by 9061 and 9473 . However, all conductors exhibit a significant improvement over 8151.

As is apparent from the discussion above, the key focus for conductor technology in the early seventies was improved adhesion and solder leach resistance. In an effort to increase the acceptance of silver-bearing conductors, particularly in high reliability applications such as telecommunications, emphasis was directed toward development of systems less prone to silver migration.

Figure 7 graphically illustrates the effect of platinum and palladium content on solder leach resistance and silver migration resistance, and shows the relative metallurgy of several commercially available conductors. High palladium content tends to enhance silver migration resistance in silver-bearing conductors because palladium forms a barrier layer at the conductor surface and thereby retards silver dendrite formation. High platinum content tends to improve

FIGURE 7 Relationship between metallurgy, solder leach resistance and silver migration resistance.

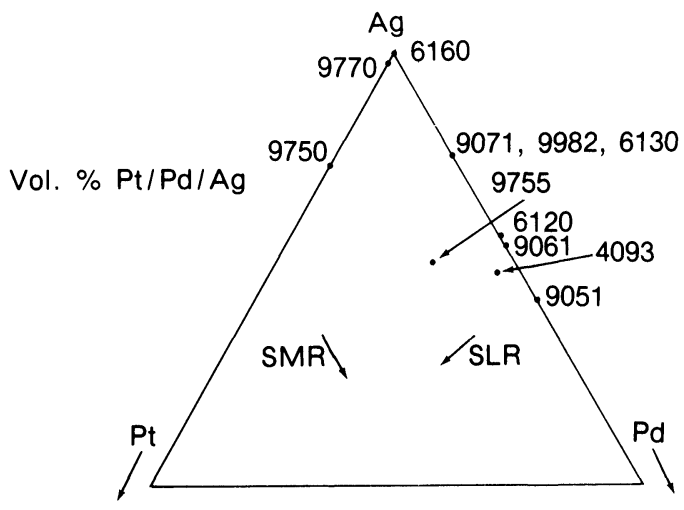


TABLE V

Solderable conductors silver migration water drop test.

\begin{tabular}{|c|c|c|c|c|c|c|}
\hline \multirow[b]{2}{*}{ Process } & \multicolumn{2}{|c|}{$\begin{array}{c}9755 \\
\mathrm{Pt} / \mathrm{Pd} / \mathrm{Ag} \\
\end{array}$} & \multicolumn{2}{|c|}{$\begin{array}{c}4093 \\
\mathrm{Pt} / \mathrm{Pd} / \mathrm{Ag} \\
\end{array}$} & \multicolumn{2}{|c|}{$\begin{array}{c}9596 \\
\mathrm{Pt} / \mathrm{Pd} / \mathrm{Au} \\
\end{array}$} \\
\hline & $\begin{array}{c}\text { Average } \\
\text { Failure } \\
\text { Time } \\
\text { (min.) }\end{array}$ & $\begin{array}{c}\text { Visible } \\
\text { Dendrite } \\
\text { Growth } \\
(30 x)\end{array}$ & $\begin{array}{c}\text { Average } \\
\text { Failure } \\
\text { Time } \\
\text { (min.) }\end{array}$ & $\begin{array}{c}\text { Visible } \\
\text { Dendrite } \\
\text { Growth } \\
(30 x)\end{array}$ & $\begin{array}{c}\text { Average } \\
\text { Failure } \\
\text { Time } \\
\text { (min.) }\end{array}$ & $\begin{array}{c}\text { Visible } \\
\text { Dendrite } \\
\text { Growth } \\
(30 x)\end{array}$ \\
\hline Conductor fired $850^{\circ} \mathrm{C}$ & 3 & Severe & 20 & Severe & $>30$ & None \\
\hline Conductor fired $925^{\circ} \mathrm{C}$ & 14 & Severe & $>30$ & Trace & $>30$ & None \\
\hline Conductor fired over, & & & & & & \\
\hline dielectric at $925^{\circ} \mathrm{C}$ & $>30$ & Trace & $>30$ & Trace & - & - \\
\hline Dielectric fired over conductor & $>30$ & None & $>30$ & None & - & - \\
\hline \multicolumn{7}{|l|}{ Dielectric: 9429} \\
\hline onditions of Test: 10 volts ac & s a 10 & ap, te & rmina & ter 30 & & \\
\hline
\end{tabular}

solder leach resistance due to its low solubility in lead/tin solders.

The first Du Pont conductor developed explicitly to achieve a good balance of silver migration resistance and solder leach resistance was 9755 , a ternary $\mathrm{Pd} / \mathrm{Pt} / \mathrm{Ag}$ composition. A lower cost mixed bonded version was subsequently developed to meet more demanding silver migration criteria at some expense to solder leach resistance. The new conductor, 4093 $\mathrm{Pd} / \mathrm{Pt} / \mathrm{Ag}$, offers significantly better silver migration resistance than 9755 and approaches that of platinum gold conductors (Table V). Tests in our laboratory also show that silver migration resistance is enhanced when the conductor is processed on a dielectric. The dielectric retards the flow of $\mathrm{Bi}_{2} \mathrm{O}_{3}$ from the conductor during firing and reduces the probability of bismuth ion migration. Higher firing temperature and encapsulating the conductor with dielectric also give progressive improvements in silver migration resistance.

Adhesion values of 9755 and 4093 before and after high temperature aging are presented in Table VI. Both conductors have excellent adhesion and show minimal degradation after thermal aging. Solder leach resistance in $63 \mathrm{Sn} / 37 \mathrm{~Pb}$ and $62 \mathrm{Sn} / 36 \mathrm{~Pb} / 2 \mathrm{Ag}$ solders is given in Table VII. The solder leach resistance of 9755 is
TABLE VII

Solder leach resistance of $\mathrm{Ag} / \mathrm{Pd} / \mathrm{Pt}$ conductors.

\begin{tabular}{lcc}
\hline & 9755 & 4093 \\
\hline $63 \mathrm{Sn} / 37 \mathrm{~Pb}$ & 18 & 11 \\
$250^{\circ} \mathrm{C}$, & & \\
(Number of 10 Second Dips) & & \\
$62 \mathrm{Sn} / 36 \mathrm{~Pb} / 2 \mathrm{Ag}$ & 30 & 15 \\
$230^{\circ} \mathrm{C}$, & & \\
(Number of 10 Second Dips) & & \\
\hline
\end{tabular}

about $60 \%$ higher than 4093 in $63 \mathrm{Sn} / 37 \mathrm{~Pb}$ solder and a factor of 2 higher then 4093 in $62 \mathrm{Sn} / 36 \mathrm{~Pb} / 2 \mathrm{Ag}$ solder.

Although the water drop test can quantify differences in silver migration resistance of various unsoldered conductors, results in our laboratory and elsewhere ${ }^{5}$ indicate that lead and tin present in the soldered conductors can show ionic migration rates similar to silver under some conditions. Table VIII illustrates water drop test results for a $\mathrm{Pt} / \mathrm{Au}$ and two $\mathrm{Pd} / \mathrm{Ag}$ conductors, both unsoldered and soldered. The rate of failure of the $\mathrm{Pt} / \mathrm{Au}$ and $4093 \mathrm{Pd} / \mathrm{Ag}$ conductors is determined by the solder due to lead ion migration,
TABLE VI

Comparison of adhesion for 9755 and 4093.

\begin{tabular}{|c|c|c|c|c|}
\hline \multirow{3}{*}{$\begin{array}{l}\frac{9755}{24 \mathrm{Hrs} .,} \mathrm{RT} \\
48 \mathrm{Hrs}, 1^{\circ} \mathrm{C} \\
100 \mathrm{Hrs} ., 150^{\circ} \mathrm{C}\end{array}$} & \multicolumn{4}{|c|}{ Adhesion, Newtons (minimum) } \\
\hline & \multicolumn{2}{|c|}{$1 \times 850^{\circ} \mathrm{C}$} & \multicolumn{2}{|c|}{$5 \times 850^{\circ} \mathrm{C}$} \\
\hline & $\begin{array}{l}24 \\
24 \\
23\end{array}$ & $\begin{array}{l}(20) \\
(22) \\
(17)\end{array}$ & $x$ & 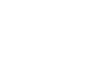 \\
\hline \multicolumn{5}{|l|}{$\underline{4093}$} \\
\hline $\begin{aligned} & 24 \mathrm{Hrs} ., \mathrm{RT} \\
& 48 \mathrm{Hrs},{ }^{\circ} 150^{\circ} \mathrm{C} \\
& 100 \mathrm{Hrs}, 1^{\circ} \mathrm{C} \\
& 1000 \mathrm{Hrs} ., 150^{\circ} \mathrm{C}\end{aligned}$ & $\begin{array}{l}27 \\
21 \\
21 \\
22\end{array}$ & $\begin{array}{l}(24) \\
(18) \\
(16) \\
(17)\end{array}$ & $\begin{array}{l}25 \\
23 \\
23\end{array}$ & $\begin{array}{l}(23) \\
(19) \\
(20)\end{array}$ \\
\hline
\end{tabular}

TABLE VIII

Water drop test on soldered and unsoldered conductors.

\begin{tabular}{ll}
\hline Conductor Code & Time to Failure \\
\hline $9596 \mathrm{Pt} / \mathrm{Au}$ (Unsoldered) & $>30$ minutes \\
$9596 \mathrm{Soldered}$ & $16-20$ seconds \\
$4093 \mathrm{Pd} / \mathrm{Ag}$ (Unsoldered) & 20 minutes \\
$4093 \mathrm{Soldered}$ & $16-20$ seconds \\
$9061 \mathrm{Pd} / \mathrm{Ag}$ (Unsoldered) & 16 seconds \\
$9061 \mathrm{Soldered}$ & $16-20$ seconds \\
\hline \\
\hline Conditions of Test: \\
1 Volt/mil for $10 \mathrm{mil}$ lines and spaces \\
Solder $62 \mathrm{Sn} / 36 \mathrm{~Pb} / 2 \mathrm{Ag}$
\end{tabular}


not by the conductor metallurgy. The unsoldered $\mathrm{Pt} / \mathrm{Au}$ and $4093 \mathrm{Pd} / \mathrm{Ag}$ conductors fail in 20 minutes or more under a $1 \mathrm{volt} / \mathrm{mil}$ bias, whereas the soldered conductors fail in 16-20 seconds. The failure rate for soldered and unsoldered $9061 \mathrm{Pd} / \mathrm{Ag}$ conductor is about the same, 16-20 seconds.

In typical electronic applications where condensation is not of concern, silver migration becomes a function of various other factors as shown in Table IX. The probability of migration is highest when high voltage gradients are used at relative humidities approaching $100 \%$. Since these conditions do not exist in typical operations, field failures due to silver migration are rare.

TABLE IX

Factors which affect the rate of silver migration.

- Nature of the Substrate............The more hygroscopic the surface of
the insulator the more likely silver
migration will occur.

\subsection{Bonding Mechanisms}

One of the most important factors determining fired thick film conductor adhesion performance is the chemistry of the permanent binder. Three binder types are commonly used in thick film conductors:

1) glass,

2) oxide and

3) glass + oxide.

Each has advantages and disadvantages. In glassbonded systems, the glass typically migrates to the substrate-metal interface during firing due to wetting phenomena. Fingers of glass extend from the substrate into the metal film and sometimes to the surface of the conductor to form a mechanical bond. In excessively high firing temperature profiles glass may "float" to the conductor surface and result in poor solderability, adhesion and wire bondability. Adhesion in oxide bonded systems is effected by a chemical bond. Copper oxide has been widely used since at high temperatures it can react with the alumina substrate to form $\mathrm{CuAlO}_{2}$.

The total volume percent of binder needed for high adhesion in glass-bonded systems is typically much greater than for oxide bonded compositions, e.g., $20-30 \%$ versus $<10 \%$. Consequently, oxide bonding generally results in higher density metal films. To achieve optimum adhesion, it is often necessary to fire oxide bonded conductors at somewhat higher temperatures than glass bonded ones. However, oxide bonded systems which can be fired as low as $850^{\circ} \mathrm{C}$ are available. The low volume percent of binder with oxide bonded systems gives rise to a clean metal-rich surface that typically has excellent solderability and wire bondability.

It is often possible to attain a good balance of conductor properties and a wider firing temperature latitude by combining both types of binder technology to achieve better control of the composite binder viscosity. Furthermore, since the oxide portion contributes significantly to the total adhesion, the volume percent of binder needed for optimum adhesion performance is less than "pure" glass-bonded systems.

A common binder component in most solderable conductor systems is bismuth oxide, a constituent that facilitates solderability and adhesion. Bismuth oxide wets the metal surface, thereby providing a "fluxing" action to remove unwanted oxides or glass. It improves efficiency of other binder constituents such as glass and oxides by facilitating their flow and migration to the conductor-substrate interface. Bismuth oxide also provides a means of achieving good adhesion to alumina substrates, presumably due to its excellent wetting and formation of $(\mathrm{Bi}, \mathrm{Al})_{2} \mathrm{O}_{3}$ solid solutions.

To attain a more detailed understanding of the functionality of $\mathrm{Bi}_{2} \mathrm{O}_{3}$ in thick film conductors, the chemistry of $\mathrm{Bi}_{2} \mathrm{O}_{3}$ was explored in relation to typical conditions experienced in actual use. Films of $\mathrm{Bi}_{2} \mathrm{O}_{3}$ on 96\% alumina substrates were prepared by screen printing a dispersion of $\mathrm{Bi}_{2} \mathrm{O}_{3}$ in an ethyl cellulose vehicle, drying the film at $150^{\circ} \mathrm{C}$ and firing in a belt furnace using a typical $850^{\circ} \mathrm{C}$ profile. The printed area was sufficiently large to permit X-ray analysis.

The initial experiment was designed to demonstrate the stability of $\mathrm{Bi}_{2} \mathrm{O}_{3}$ films to molten $\mathrm{Sn} / \mathrm{Pb}$ solder. The fired $\mathrm{Bi}_{2} \mathrm{O}_{3}$ film was fluxed with Alpha 611 and dipped into a $62 \mathrm{Sn} / 36 \mathrm{~Pb} / 2 \mathrm{Ag}$ solder pot at $220^{\circ} \mathrm{C}$ for 10 seconds. The film, which was yellowish in color before dipping, was black when removed. An X-ray diffraction pattern of the film revealed that the discoloration was due to formation of bismuth metal.

$\mathrm{Bi}_{2} \mathrm{O}_{3}$ films were tested also under various fluxing conditions to determine if the bismuth oxide-bismuth transformation was due to the fluxing agent or the molten solder (Table X). Regardless of flux type used (Alpha 611, Alpha 100, or Dutch Boy 115), a 
TABLE $X$

Effect of flux activity on formation of Bisumth metal from $\mathrm{Bi}_{2} \mathrm{O}_{3}$.

\begin{tabular}{lll}
\hline \multicolumn{1}{c}{ Flux } & Discoloration & $\mathrm{X}$-Ray Analysis \\
\hline Alpha 611 & Black (Intense) & $\mathrm{Bi}_{2} \mathrm{O}_{3}+\mathrm{Bi}$ \\
Alpha 100 & Black (Moderate) & $\mathrm{Bi}_{2} \mathrm{O}_{3}+\mathrm{Bi}$ \\
$\mathrm{DB} \mathrm{115}$ & Black (Intense) & $\mathrm{Bi}_{2} \mathrm{O}_{3}+\mathrm{Bi}$ \\
Glycerine & Black (Moderate) & $\mathrm{Bi}_{2} \mathrm{O}_{3}+\mathrm{Bi}$ \\
None & Dark & $\mathrm{Bi}_{2} \mathrm{O}_{3}+\mathrm{Bi}$ \\
\hline Conditions: & $62 \mathrm{Sn} / 36 \mathrm{~Pb} / 2 \mathrm{Ag}$ Solder \\
& $220^{\circ} \mathrm{C}$ \\
& $20 \mathrm{Second}$ Dip &
\end{tabular}

moderate-to-intense discoloration was observed when the $\mathrm{Bi}_{2} \mathrm{O}_{3}$ film was immersed in molten solder. Similar results were obtained with glycerine, generally not thought to be a fluxing agent. Discoloration also occurred when no fluxing agent was used, although noticeably less than the fluxed films. In all cases X-ray diffraction showed the presence of bismuth metal. The observed discoloration was not due to the combined effects of fluxing agent and temperature. No discoloration was observed when fluxed parts were heated to $230^{\circ} \mathrm{C}$ for 20 seconds to several minutes.

The conclusion drawn from these experiments is that molten $\mathrm{Sn} / \mathrm{Pb}$ solders are sufficiently strong reducing agents to reduce bismuth oxide to bismuth metal. The chemical reaction is presumably

$$
2 \mathrm{Bi}_{2} \mathrm{O}_{3}+3 \mathrm{Sn} \rightarrow 4 \mathrm{Bi}+3 \mathrm{SnO}_{2}
$$

This model is extremely useful in explaining both the solderability and adhesion characteristics of thick film conductors. Solderability of $\mathrm{Bi}_{2} \mathrm{O}_{3}$-containing conductor compositions is facilitated because a thin coating of the bismuth oxide or bismuth oxide-containing glass on the conductor surface can easily be removed by the molten $\mathrm{Sn} / \mathrm{Pb}$ solder. The presence of $\mathrm{Bi}_{2} \mathrm{O}_{3}$ which greatly assists the formation of a bond between the metals and the substrate during firing of the conductor also provides a point of attack by the solder on the binder network during thermal aging. Tin metal from the solder can diffuse along grain boundaries of the metal and bismuth oxide-containing filaments which permeate the thick film, and reduce bismuth oxide to bismuth metal. Degradation in adhesion is most severe when the layer of bismuth oxide at the alumina-metal interface is destroyed. Conductor swelling caused by tin diffusion into the film and subsequent inter-metallic formation $\left(\mathrm{PdSn}_{3}\right)$ is undoubtedly occurring along with the reduction phenomenon. Both processes weaken the metalsubstrate bond. However, bond deterioration due to bismuth oxide reduction is believed to be the rate-determining step.

Although bismuth oxide is degraded rapidly by solder metals (particularly tin), bismuthate glasses such as the one used in $9061 \mathrm{Pd} / \mathrm{Ag}$ show much better chemical durability. While some reduction of bismuth oxide can also occur in these glasses, the glassy matrix integrity is maintained due to the overall lowering of chemical reactivity.

The specific binder choice dramatically affects the chemical durability and consequently the solderability and adhesion performance of a thick film conductor. Most of the conductor systems developed since 1970 have employed mixed bonding. Careful choice of the glass and oxide components can give a binder with excellent chemical durability as well as the flow and wetting properties necessary for good conductor solderability and high adhesion.

\subsection{Vehicle Technology of Conductors}

Over the past ten years the emphasis in vehicle research has shifted from the development of conductors with high resolution capabilities to materials with uniform and reliable printing characteristics over extended periods of time at high squeegee speeds. This trend evolved from the increasing applications in automotive, telecommunications, and consumer electronics where high throughput could be utilized effectively to reduce overall circuit costs. This section describes vehicle technology and discusses its evolution from the simple polymer/solvent systems used for traditional applications to complex systems designed for process sensitive high volume operations.

The chief function of the screening vehicle is to maintain the inorganic particulates in a desirable state of dispersion and to allow easy transfer of paste through the screen and onto the substrate without paste spreading. The solvent of the vehicle should evaporate slowly at ambient temperatures to insure long residence times on the screen during use but must dry easily at elevated temperatures to provide films sufficiently strong to withstand normal handling. Additionally, the vehicle should burn out easily and completely when fired. Other important functions include long shelf life, a low order of toxicity, chemical inertness to preclude reactions with the screen or solids, a small change in viscosity with change in ambient temperature, and solubility in other solvents to permit easy cleanup.

A resin with polar groups on the polymer chain is desirable to obtain an adequate dispersion of metals and glasses. The resin should provide good viscosity build at low concentrations and burn cleanly during the early stages of the thick film firing cycle. Cellulose ethers such as ethyl cellulose give a good balance of 
these properties and have historically been used by thick film paste manufacturers. Although the resin generally imparts adequate "green strength" to the dried film, wetting agents and other additives compatible with the resin are frequently used to achieve a good bond between the inorganic particulates and between the composite and substrate.

Solvents with a vapour pressure of $<0.2 \mu \mathrm{m}$ at $20^{\circ} \mathrm{C}$ and boiling points in the range of $200-300^{\circ} \mathrm{C}$ at $760 \mathrm{~mm} \mathrm{Hg}$ are generally used in vehicle formulations. Vehicles comprised of solvents with very low vapor pressures and boiling points above $300^{\circ} \mathrm{C}$ are difficult to dry under conditions typically used in printing operations, e.g., $5-10$ minutes at $125-150^{\circ} \mathrm{C}$. By balancing the interactions between the solvent and the resin, the change in vehicle viscosity with temperature can be minimized. To insure a long shelf life, factors such as water absorption by the vehicle, reactions between functional groups on the solvent or resin and the solids, air oxidation, and other reactions must be controlled. This is an area where considerable expertise is required on the part of the paste manufacturers since many of the inorganic solids used in thick film compositions are excellent catalysts for the promotion of reactions by organic molecules.

Resins must remain freely soluble in common solvents before and after drying, so that both substrates and printing tools may be cleaned easily. Thus, thermoset crosslinking resins are unacceptable in thick film vehicles. Common cleanup solvents are trichloroethane, Freon ${ }^{\circledR}$, xylene, trichloroethylene and butanol.

The vehicle contributes significantly to the flow behavior or rheology of a composition. Other major factors include particle size, particle morphology and volume fraction of the dispersed solids. Viscosity is the most widely used parameter for assessing a composition's flow behavior. It is the internal resistance exerted by a fluid to the relative motion of its parts, and is expressed in units of Pascal Seconds (Pa.S). It is defined as shear stress divided by shear rate, where shear stress is the force in Pascals applied to a viscous fluid to cause its movement, and shear rate in seconds ${ }^{-1}$ is the rate of travel of two parallel plates separated by fluid, divided by distance between plates $\left((\mathrm{cm} / \mathrm{sec}) / \mathrm{cm}=\mathrm{sec}^{-1}\right)$.

Conductor compositions are formulated to exhibit pseudoplastic or thixotropic flow behavior. These respond to shear with a decrease in viscosity and recovery to high viscosity on cessation of shear. However, a thixotropic material exhibits time dependence, i.e., viscosity at a given shear rate decreases with increasing time of shear. Also, as the paste is subjected to a range of shear rates, first increasing and then decreasing, paste viscosity at the same shear rate is less during the decreasing part of the cycle. This behavior tends to permit levelling of screen mesh marks on print surfaces but is conducive to line spreading. The degree of thixotropy is important in balancing these phenomena. When shear rate is increased tenfold, a typical conductor paste decreases in viscosity to $15-30 \%$ of its value at the lower shear rate.

Table XI lists shear rates that are operative during key steps in the printing operation (levelling, screening, paste transfer) and presents typical viscosicies at these shear rates for pastes designed for either high speed or high resolution printing. The major differences in viscosity behavior occur at the high shear rate.

Viscosity/shear rate curves are obtained from a variety of instruments. Since the viscosity value at a given rate of shear is usually a steady state measurement, the viscosity/shear rate curve does not fully define the shear thinning behavior of a paste when it is subjected to a short burst of high shear as during paste transfer through the screen.

Nevertheless, the steady state values of $80-400 \mathrm{sec}^{-1}$ often allow one to predict the relative performance of inks during transfer of paste through the screen.

Early vehicle systems, composed of solvent(s), ethyl cellulose and generally a flow control additive, permitted the formulation of conductor systems that gave good line resolution and good printing at moderate squeegee speeds of 7 to $12 \mathrm{~cm} / \mathrm{sec}$. However, by 1975 a number of applications existed that required high printing speeds and long production runs. For these applications, new developments were required to improve paste transfer through the screen and to prolong paste residence time on the screen without adverse changes in viscosity or printed line resolution. Accordingly, new vehicle technology based on considerations of polymer solvent interactions and polymer solubility characteristics in solvent systems as a function of temperature was developed. Vehicles

TABLE XI

Shear rate - viscosity characteristics for various screen printing operations.

\begin{tabular}{|c|c|c|c|}
\hline \multirow[b]{2}{*}{$\begin{array}{l}\text { Shear Rate } \\
\left(\text { Second }^{-1}\right)\end{array}$} & \multirow{2}{*}{$\begin{array}{c}\text { Corresponding } \\
\text { Printing } \\
\text { Operation } \\
\end{array}$} & \multicolumn{2}{|c|}{ Viscosity $(\mathrm{Pa} \bullet \mathrm{S})$} \\
\hline & & $\begin{array}{l}\text { High Speed } \\
\text { Printing }\end{array}$ & $\begin{array}{l}\text { High Resolution } \\
\text { Printing }\end{array}$ \\
\hline 0.2 & Leveling & $600-900$ & $800-1300$ \\
\hline 4 & $\begin{array}{l}\text { Pushed on Screen } \\
\text { by Squeegee }\end{array}$ & $80-200$ & $200-300$ \\
\hline 80 & Rapid Stirring & $40-60$ & $60-80$ \\
\hline 350 & $\begin{array}{l}\text { Transfer } \\
\text { Through Screen }\end{array}$ & $15-25$ & $25-40$ \\
\hline
\end{tabular}




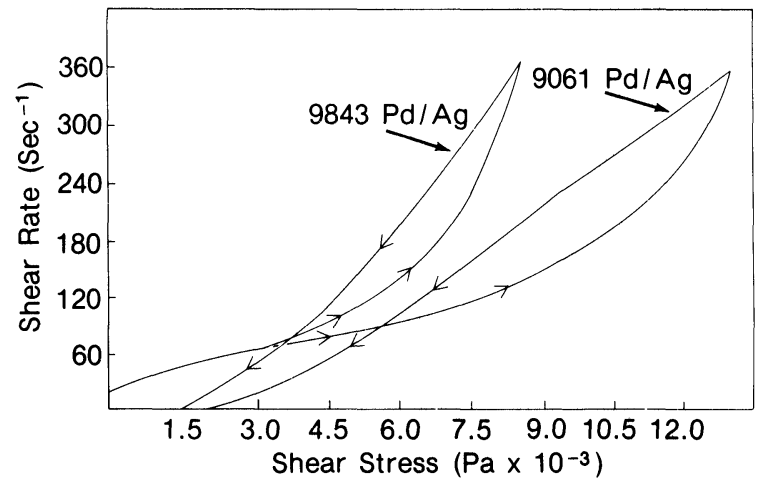

FIGURE 8 Shear rate vs. shear stress for 9061 and 9843 $\mathrm{Pd} / \mathrm{Ag}$ conductors.

derived from this technology gave lower viscosity at high shear to facilitate easier paste transfer, a lower rate of solvent evaporation from the paste and a reduced rate of viscosity increase at a given rate of evaporation. (These vehicle systems are designated by Du Pont as Sprint $^{\mathrm{TM}}$.)

Figure 8 illustrates the rheograms of $\mathrm{Pd} / \mathrm{Ag}$ conductor compositions 9843 (Sprint ${ }^{\mathrm{TM}}$ vehicle) and 9061 (conventional vehicle) obtained from a Ferranti-Shirley viscometer with a cone angle of $1.0^{\circ}$. The maximum shear rate measured was limited to 350 $\sec ^{-1}$ because of edge failure, particularly with 9061 . Edge failure is a phenomenon which occurs on cone/plate viscometers with high viscosity fluids at high shear rates. The material at the edge of the cone breaks away from the cone, resulting in erroneously low shear stress readings at high shear rates. Compared to 9061 the shear stress and viscosity of 9843 are considerably lower at all shear rates.

Since viscosity is a time dependent phenomenon, shear stress data taken with an applied shear of relatively short time duration is more indicative of screen transfer of paste than steady state measurements. By using spring relaxation measurements, high shear rates can be obtained more quickly than by using a conventional motor drive on the Ferranti-Shirley viscometer. Spring relaxation measurements are made by winding up the spring on the measuring head of the Ferranti-Shirley or other similar cone/plate viscometer, and allowing the spring, rather than the motor, to provide the shear stress for the measurement.

The viscosity measured at various shear rates by spring relaxation is plotted for 9843 and 9061 in Figure 9. The rapid response of 9843 to shear stress is even more apparent compared to 9061 under these conditions. The quicker response of the Sprint ${ }^{\mathrm{TM}}$ vehicle present in 9843 is related to rapid breakdown of the gel structures that set up in the absence of shear. Shear thinning is a function of the interactions between the solids and the vehicle. Factors such as the degree of polymer adsorption to the solids and degree of solids

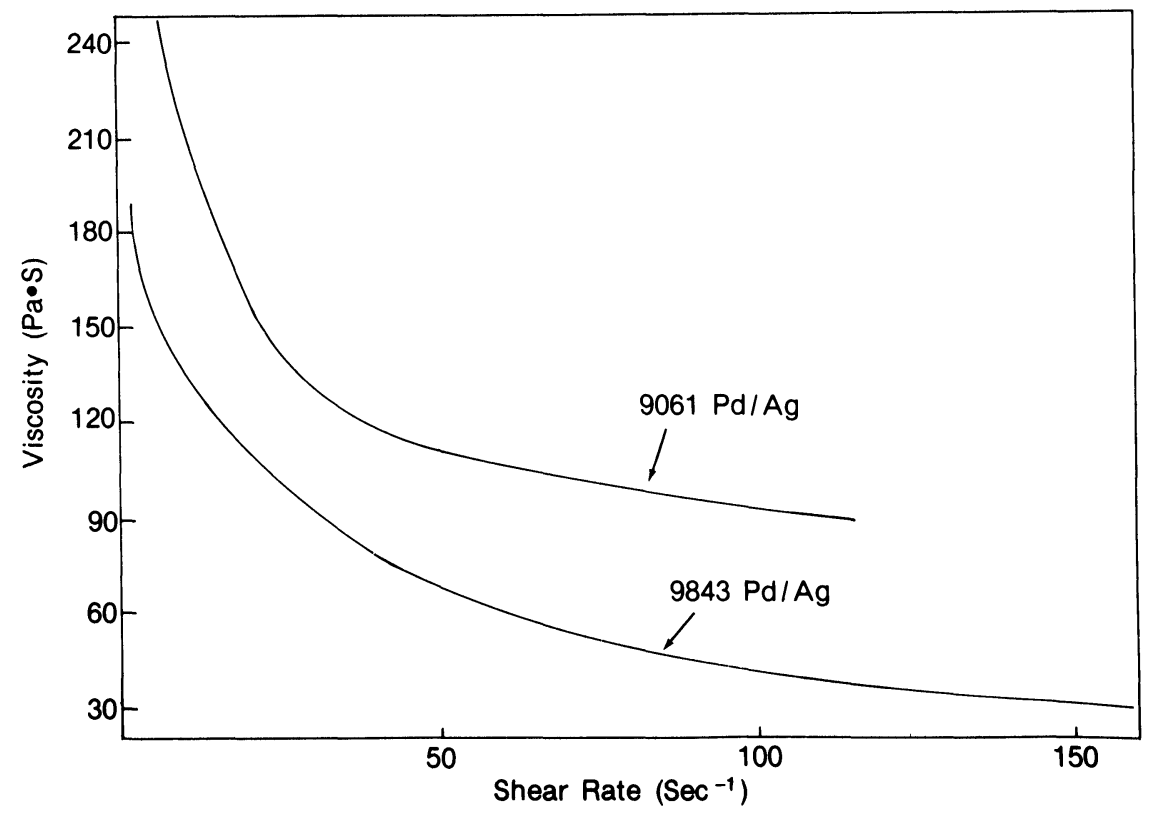

FIGURE 9 Viscosity - shear rate characteristics of 9061 and 9843 Pd/Ag conductors. 


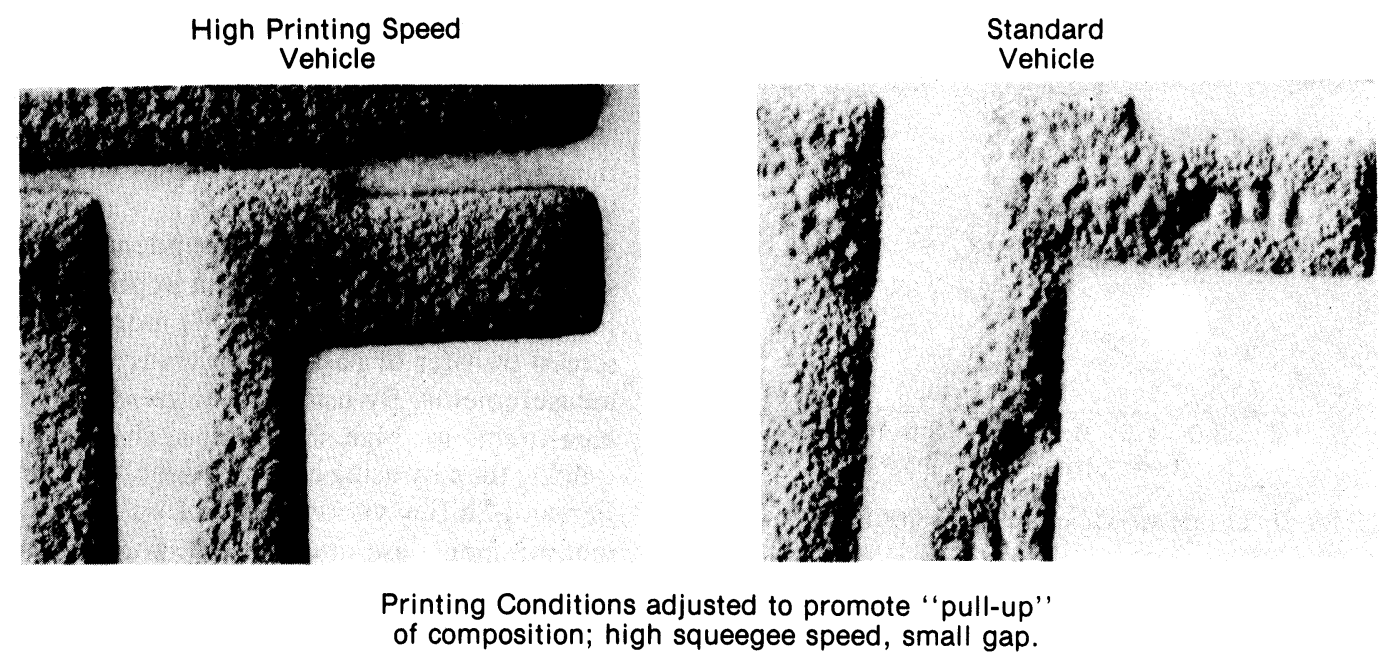

FIGURE 10 Optical photomicrographs $(31 \times)$ of Pd/Ag conductors - surfaces of dried prints.

wetting by the solvent greatly influence the rate and the amount of shear thinning in thick film compositions. The rapid reduction of viscosity during shear of these newer vehicle systems greatly facilitates the paste transfer and quality of the resultant print in high speed printing operations. Figure 10 shows optical photomicrographs of surfaces of dried prints produced with 9843 and 9061 . Printing conditions were adjusted to promote void formation: very high squeegee speed, small initial gap between the screen and the substrate. It is clear that the print of 9843 , formulated with the vehicle for high speed printing, exhibits the smoother surface, free of imperfections evident in 9061.

The knowledge of solvent/polymer interactions and

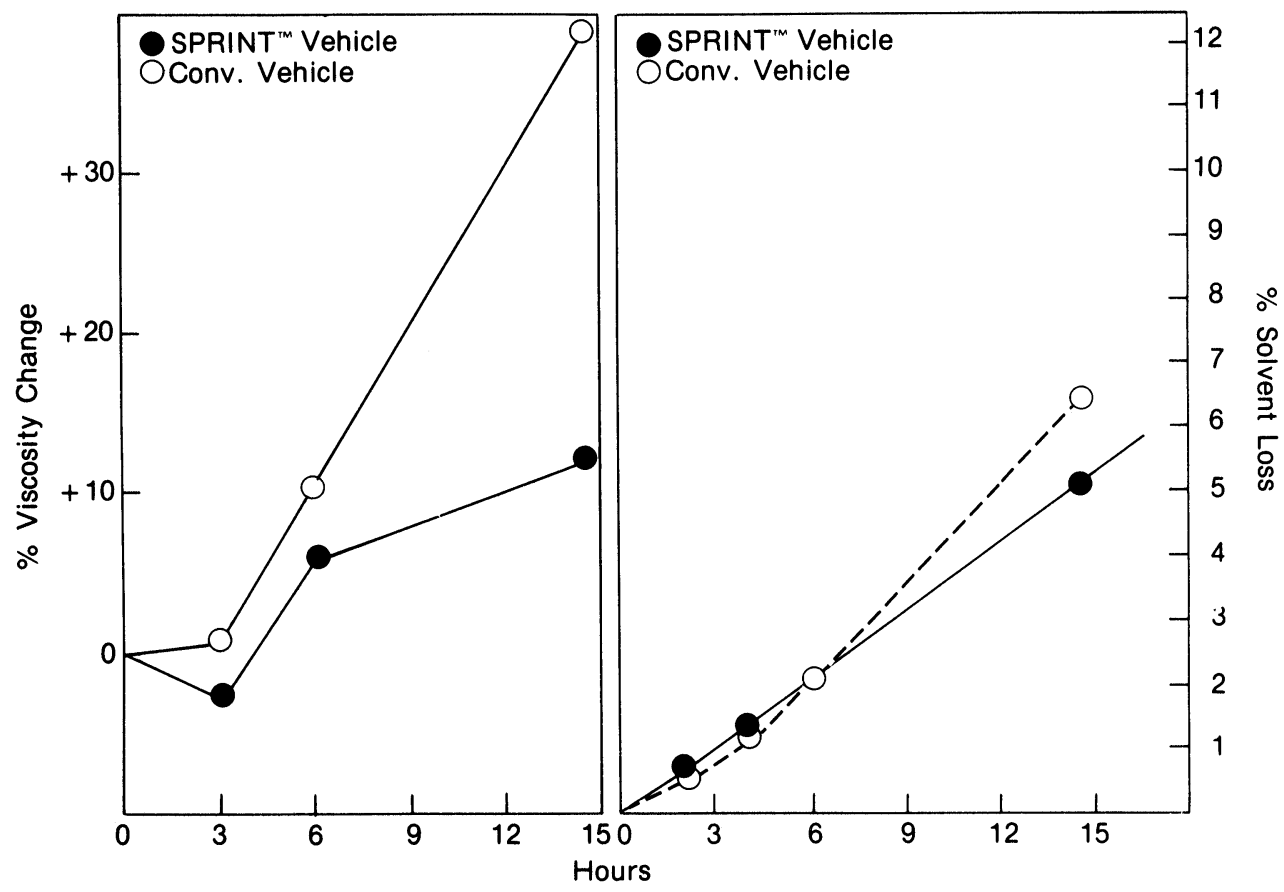

FIGURE 11 Drying characteristics of sprint and conventional vehicle systems. 
polymer solubility characteristics during solvent evaporation from mixed solvent systems has been effectively used to develop vehicle systems whose viscosity is less sensitive to change in polymer concentration. Figure 11 compares the drying behaviour of pastes formulated with new and conventional vehicle systems. In this test $13 \mathrm{~cm}^{2}$ areas were covered with 1.5 grams of each paste and allowed to dry at $21^{\circ} \mathrm{C}$ in air. Viscosity increase and weight loss were recorded as a function of time. The difference in weight loss between the two compositions is not large due to similar vapor pressures within the two systems. However, the rate of viscosity increase for 9843 is dramatically lower than that of 9061 over a period of 15 hours - an excellent example of how solvent properties other than vapor pressure influence paste residence time on a screen.

Polymer/solvent interactions are also important in determining the sensitivity of viscosity to temperature change. Figure 12 illustrates the difference in viscosity-temperature response between conventional vehicle technology, present in 9061, and newer vehicle technology, present in 9843 . The new vehicle system provides a twofold reduction in the sensitivity of

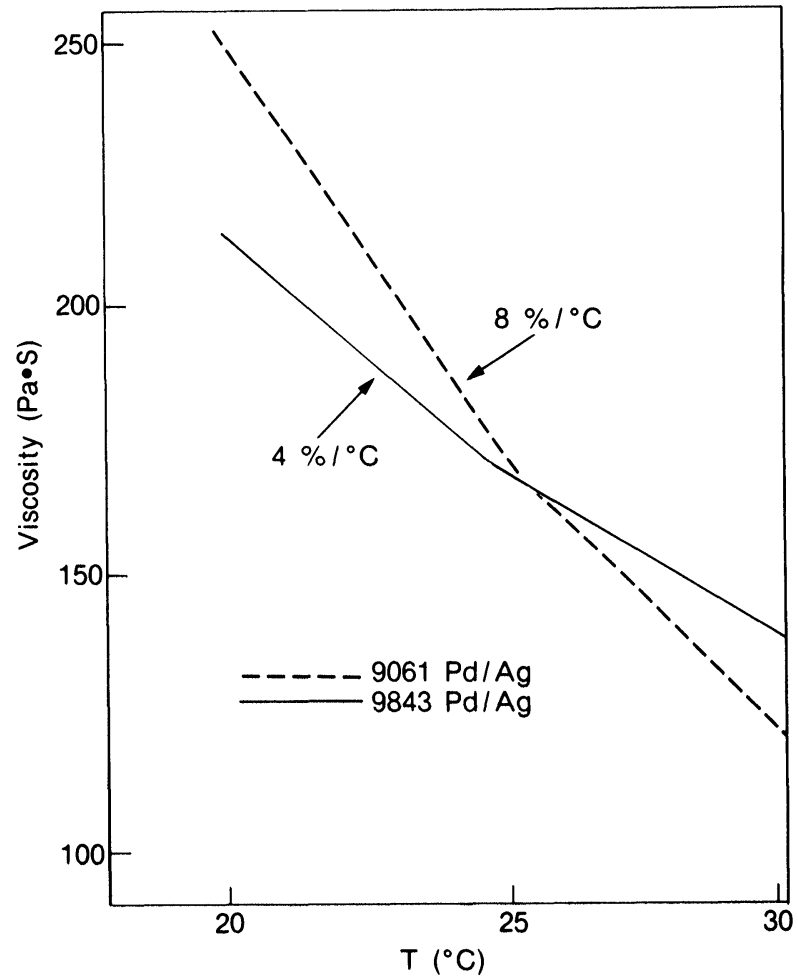

FIGURE 12 Viscosity vs. temperature for 9061 and 9843 $\mathrm{Pd} / \mathrm{Ag}$ conductors. viscosity to temperature, an important factor in printing operations where large temperature excursions occur.

High resolution pastes require somewhat different viscosity and shear response than compositions designed primarily for high speed printing. For example, a typical paste designed for high speed printing (see Table XI) will have a viscosity of 20-30 $\mathrm{Pa} . \mathrm{S}$ at $200 \mathrm{sec}^{-1}$, whereas a high resolution composition would have a viscosity of $40-50 \mathrm{~Pa} . \mathrm{S}$ at $200 \mathrm{sec}^{-1}$. Since the rest viscosity does not affect paste transfer through the screen, the viscosity of the high speed printing composition at $0.1 \mathrm{sec}^{-1}$ would not be much below that of a composition designed for high resolution work. Therefore, the shear thinning characteristic of a composition designed for high resolution applications will not be as pronounced as that of a composition designed for high speed printing.

\subsection{Recent Conductor Developments}

The emphasis in conductor research over the past two-three years has been directed toward development of lower cost systems with performance characteristics approaching those of the higher cost palladium-silver conductors. During this time considerable effort has focused on new binder systems and new powder morphologies to obtain highly adherent dense fired films which offer good leach resistance to solder despite their increasingly high silver contents. The general purpose microcircuit conductors evolving from this work include $6120 \mathrm{Pd} / \mathrm{Ag}, 6130 \mathrm{Pd} / \mathrm{Ag}$ and $6160 \mathrm{Ag}$ compositions.

Conductors 6120 and $6130 \mathrm{Pd} / \mathrm{Ag}$ were introduced commercially nearly two years ago. The features of 6120 include $10-15 \%$ greater coverage than similar products such as 9061 or 9473 , compatibility with resistors and the full range of low- $K$ and high- $K$ dielectrics, good resistance to silver migration and to solder leaching in $62 \mathrm{Sn} / 36 \mathrm{~Pb} / 2 \mathrm{Ag}$ and $63 \mathrm{Sn} / 37 \mathrm{~Pb}$ solders. The attributes of $6130 \mathrm{Pd} / \mathrm{Ag}$ are low resistivity (10-15 $\mathrm{m} \Omega / \square)$, good resistance to solder leaching in $62 \mathrm{Sn} / 36 \mathrm{~Pb} / 2 \mathrm{Ag}$ and $63 \mathrm{Sn} / 37 \mathrm{~Pb}$ solders and compatibility with resistors and cross-over dielectrics. Because of the higher $\mathrm{Ag} / \mathrm{Pd}$ ratio of 6130 , it also offers additional cost savings over 9061-type conductors. Both 6120 and 6130 are formulated in Du Pont's Sprint ${ }^{\mathrm{TM}}$ vehicle system which permits squeegee speeds up to $30 \mathrm{~cm} / \mathrm{sec}$ and long production runs for maximum throughput. Both conductors also have a mixed binder system, which affords high initial and long term aged adhesion plus excellent solder acceptance. Table XII summarizes the adhesion 
TABLE XII

Comparison of adhesion and solder leach results for low cost conductors.

\begin{tabular}{|c|c|c|c|c|c|c|}
\hline \multirow[b]{2}{*}{ Adhesion, Newtons (minimum) } & \multicolumn{6}{|c|}{ Product Code } \\
\hline & \multicolumn{2}{|c|}{$\underline{6120}$} & \multicolumn{2}{|c|}{$\underline{6130}$} & \multicolumn{2}{|c|}{$\underline{9061}$} \\
\hline \multicolumn{7}{|l|}{$62 \mathrm{Sn} / 36 \mathrm{~Pb} / 2 \mathrm{Ag}$} \\
\hline $\begin{array}{l}24 \mathrm{Hrs}, \mathrm{RT}^{\circ} \\
100 \mathrm{Hrs} ., 150^{\circ} \mathrm{C}\end{array}$ & $\begin{array}{l}24 \\
24\end{array}$ & $\begin{array}{l}(20) \\
(20)\end{array}$ & $\begin{array}{l}23 \\
23\end{array}$ & $\begin{array}{l}(19) \\
(20)\end{array}$ & $\begin{array}{l}24 \\
23\end{array}$ & $\begin{array}{l}(21) \\
(18)\end{array}$ \\
\hline $\begin{array}{l}\frac{63 \mathrm{Sn} / 37 \mathrm{~Pb}}{24 \mathrm{Hrs} ., \mathrm{RT}} \\
100 \mathrm{Hrs} ., 150^{\circ} \mathrm{C} \\
1000 \mathrm{Hrs} ., 150^{\circ} \mathrm{C}\end{array}$ & $\begin{array}{l}24 \\
22 \\
21\end{array}$ & $\begin{array}{l}(21) \\
(20) \\
(17)\end{array}$ & $\begin{array}{l}24 \\
21 \\
18\end{array}$ & $\begin{array}{l}(21) \\
(19) \\
(14)\end{array}$ & $\begin{array}{l}24 \\
23 \\
20\end{array}$ & $\begin{array}{l}(21) \\
(20) \\
(16)\end{array}$ \\
\hline \multicolumn{7}{|l|}{ Solder Leach Resistance } \\
\hline $\begin{array}{l}62 \mathrm{Sn} / 36 \mathrm{~Pb} / 2 \mathrm{Ag} \\
230^{\circ} \mathrm{C} \\
\text { (Number of } 10 \text { second dips) }\end{array}$ & 8 & & 7 & & 1 & 0 \\
\hline $\begin{array}{l}63 \mathrm{Sn} / 37 \mathrm{~Pb} \\
250^{\circ} \mathrm{C} \\
\text { (Number of } 10 \text { second dips) }\end{array}$ & 6 & & 5 & & & 6 \\
\hline
\end{tabular}

and solder leach results for the two compositions and compares them to the higher cost $9061 \mathrm{Pd} / \mathrm{Ag}$ conductor.

Microcircuit silver composition, 6160 , has been developed recently to provide a lower cost alternative to $9770 \mathrm{Pt} / \mathrm{Ag}$. The new conductor offers excellent solderability and solder leach resistance (equivalent to $9770 \mathrm{Pt} / \mathrm{Ag}$ ) in $62 \mathrm{Sn} / 36 \mathrm{~Pb} / 2 \mathrm{Ag}$ solder, aged adhesion of about 22 newtons through 1000 hours at $150^{\circ} \mathrm{C}$ and high green strength for high throughput operations where dried parts are handled automatically. The exceptional performance in both adhesion and solder leach resistance has been achieved by improvements in metal powder technology and advances in the chemistry of inorganic binder constituents. The mixed binder system resulted from detailed mechanistic analyses of several commercially available thick film conductors and many experimental compositions. Figure 13 compares the aged adhesion of

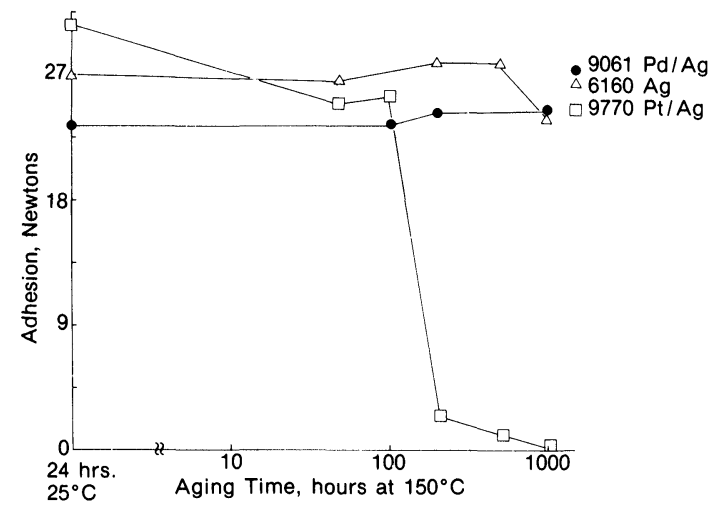

FIGURE 13 Aged adhesion vs. aging time for $9061 \mathrm{Pd} / \mathrm{Ag}$, $9770 \mathrm{Pt} / \mathrm{Ag}$ and $6160 \mathrm{Ag}$ conductors.
$9061 \mathrm{Pd} / \mathrm{Ag}, 9770 \mathrm{Pt} / \mathrm{Ag}$ and $6160 \mathrm{Ag}$ as a function of aging time for parts soldered in $62 \mathrm{Sn} / 36 \mathrm{~Pb} / 2 \mathrm{Ag}$ and aged at $150^{\circ} \mathrm{C}$. The aged adhesion of $6160 \mathrm{Ag}$ is superior to both $9770 \mathrm{Pt} / \mathrm{Ag}$ and $9061 \mathrm{Pd} / \mathrm{Ag}$.

SEM's of the fired surfaces of $9061 \mathrm{Pd} / \mathrm{Ag}, 9770$ $\mathrm{Pt} / \mathrm{Ag}$ and $6160 \mathrm{Ag}$, shown in Figure 14, reveals that 6160 has the higher surface density. SEM's of cross-sections show that the bulk film density of 6160 is significantly higher than 9061 and somewhat higher than 9770 . The surface of 6160 also has a higher percentage of metallic phase than 9061 due to the very low volume fraction of binder. The latter feature is key to the excellent solder acceptance and wire bondability of $6160 \mathrm{Ag}$. Table XIII illustrates the binder type and and volume \% binder present in several recently developed low cost systems and compares them with 9061 and 9770.

TABLE XIII

Comparison of binders for several low cost conductor systems.

\begin{tabular}{ccc}
\hline Product Code & Binder Type & Volume \% Binder \\
\hline 9061 & Glass & 26 \\
9770 & Oxide & 4 \\
6120 & Mixed & 26 \\
6130 & Mixed & 21 \\
6160 & Mixed & 4 \\
\hline
\end{tabular}

Several of the low cost systems discussed above have been evaluated for ultrasonic aluminum and thermosonic gold-wire bonding, two widely used interconnection techniques. Figures 15, 16 and 17 illustrate the bond strength versus aging time and bond resistance versus aging time for Au wire bonds to 4093 $\mathrm{Pd} / \mathrm{Pt} / \mathrm{Ag}, 6120 \mathrm{Pd} / \mathrm{Ag}$ and $9770 \mathrm{Pt} / \mathrm{Ag}$, respectively. Resistance measurements were made across a series connection of 6 conductor pads, 5 wires and 10 bonds. Both 6120 and 4093 give excellent results with no bond strength degradation or bond resistance increase through 1000 hours at $150^{\circ} \mathrm{C}$ and $200^{\circ} \mathrm{C}$. The performance of 9770 is also good, but bond resistance is observed to increase with $200^{\circ} \mathrm{C}$ storage and some bond lifts are observed after $150^{\circ} \mathrm{C}$ and $200^{\circ} \mathrm{C}$ storage. Figure 18 illustrates the bond strength and bond resistance versus aging time for thermosonic bonding to $6160 \mathrm{Ag}$ after $150^{\circ} \mathrm{C}$ storage. Through 500 hours very little change is observed in either bond strength or bond resistance.

Table XIV summarizes results for ultrasonic aluminum wire bond studies on $9071 \mathrm{Pd} / \mathrm{Ag}, 9755$ $\mathrm{Pd} / \mathrm{Pt} / \mathrm{Ag}, 6120 \mathrm{Pd} / \mathrm{Ag}, 6130 \mathrm{Pd} / \mathrm{Ag}, 9770 \mathrm{Pt} / \mathrm{Ag}$ and $6160 \mathrm{Ag}$ conductors. Through 100 hours aging at 

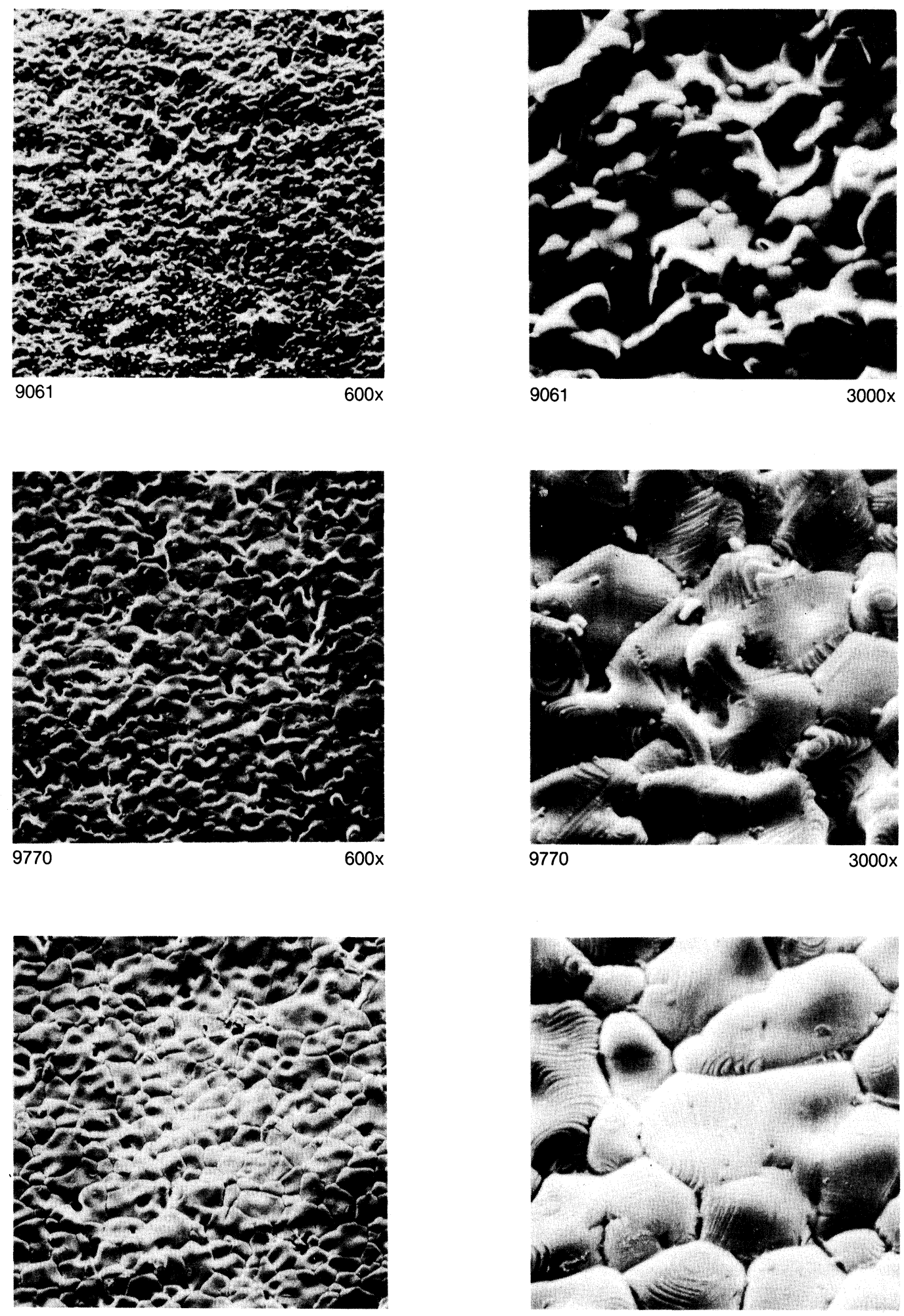

6160

$600 x$

6160

$3000 x$

FIGURE 14 SEM's of conductor surfaces. 


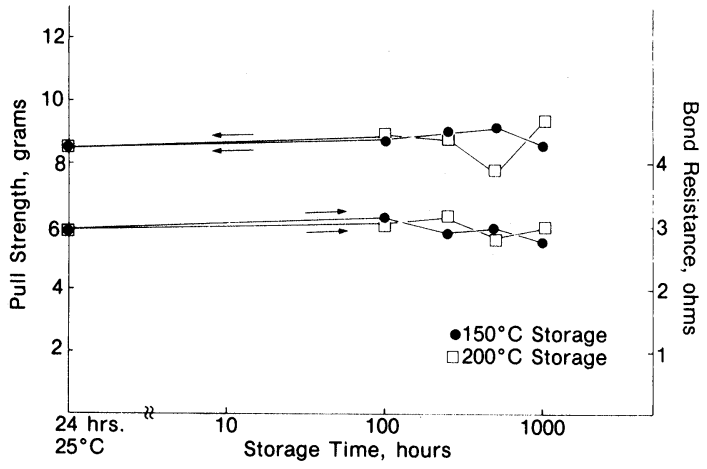

FIGURE 15 Thermosonic gold wire bonding to 4093 $\mathrm{Pt} / \mathrm{Pd} / \mathrm{Ag}$ pull strength and bond resistance vs. aging time.

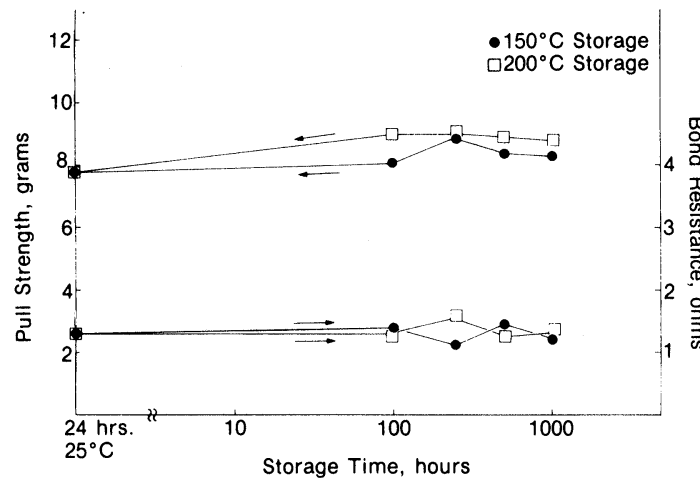

FIGURE 16 Thermosonic gold wire bonding to 6120 $\mathrm{Pd} / \mathrm{Ag}$ pull strength and bond resistance vs. aging time.

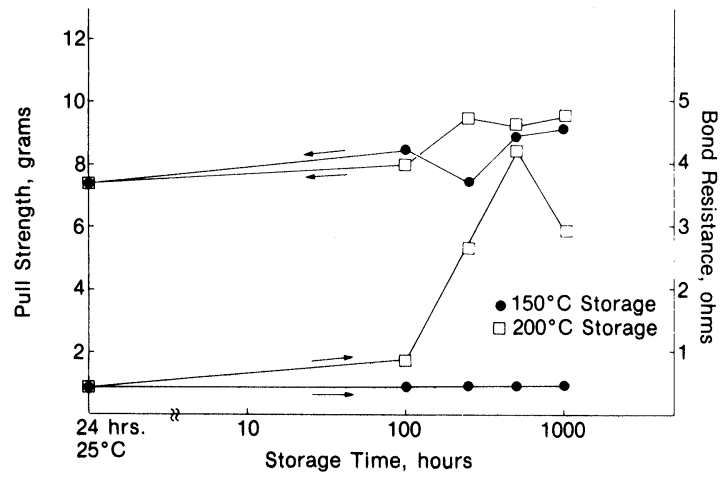

FIGURE 17 Thermosonic gold wire bonding to $9770 \mathrm{Pt} / \mathrm{Ag}$ pull strength and bonding resistance vs. aging time.

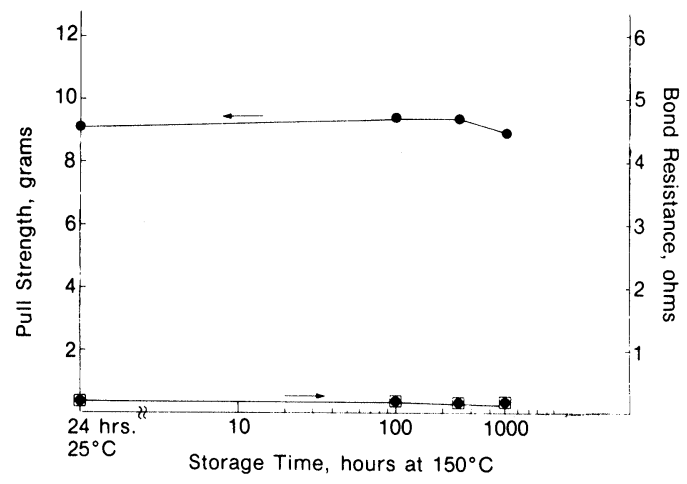

FIGURE 18 Thermosonic gold wire bonding to $6160 \mathrm{Ag}$ pull strength and bond resistance vs. aging time.

TABLE XIV

Ultrasonic aluminum-wire bond results.

\begin{tabular}{|c|c|c|c|}
\hline \multirow[t]{2}{*}{ Product Code } & \multicolumn{3}{|c|}{$\begin{array}{l}\text { Pull Strength and Failure Modes of } \\
\text { Ultrasonic Aluminum Wire Bonds } \\
\text { to Silver-Bearing Conductors }\end{array}$} \\
\hline & $24 \mathrm{Hr} ., \mathrm{RT}$ & $48 \mathrm{Hr} ., 150^{\circ} \mathrm{C}$ & $100 \mathrm{Hr} ., 150^{\circ} \mathrm{C}$ \\
\hline 9071 & $7.7(5-10)$ & $6.2(5-9)$ & $\begin{array}{l}6.2(5-9) \\
93 \% \text { Wire }\end{array}$ \\
\hline 9755 & $7.7(6-10)$ & $5.5(4-9)$ & $5.1(3-8)$ \\
\hline 6120 & $7.5(5-10)$ & $\begin{array}{l}6.5(5-9) \\
90 \% \text { Wire }\end{array}$ & $\begin{array}{l}5.6(4-8) \\
73 \% \text { Wire }\end{array}$ \\
\hline 6130 & $9.1(7-11)$ & $6.9(5-10)$ & $\begin{array}{l}7.6(5-10) \\
91 \% \text { Wire }\end{array}$ \\
\hline 9770 & $9.9(8-13)$ & $6.1(5-8)$ & $\begin{array}{l}5.0(2-8) \\
50 \% \text { Wire }\end{array}$ \\
\hline 6160 & $8.9(6-11)$ & $x$ & $\begin{array}{l}5.7(3-8) \\
94 \% \text { Wire }\end{array}$ \\
\hline
\end{tabular}

*Unless designated, all failures were $100 \%$ wire. Strength given in grams.

$150^{\circ} \mathrm{C}$ some degradation in bond strength occurs but there are no catastrophic failures. The decreased pull strength values are largely due to the annealing of the aluminum wire.

These data show that both ultrasonic aluminum and thermosonic gold wire bonding can be used satisfactorily for interconnection of IC chips with these thick film conductors. As expected, thermosonic gold wire bonding gives somewhat higher pull strengths and minimal bond lifts through 1000 hours with either $150^{\circ} \mathrm{C}$ or $200^{\circ} \mathrm{C}$ storage.

\section{CONCLUSIONS}

Low cost thick film conductor compositions developed by Du Pont over the past ten years have been reviewed. 
Several key performance characteristics were described and related to metallurgy, inorganic binder type and organic vehicle constituents. A failure mechanism to explain conductor adhesion degradation after high temperature storage has been discussed. Although conductor swelling caused by tin diffusion into the conductor film has been substantiated, the reduction of bismuth oxide by diffused tin metal and resultant formation of bismuth metal is believed to be the predominant failure mechanism.

Recent conductor technologies which have evolved over the past two years were discussed in detail and performance characteristics related to earlier, more expensive Pd/Ag conductors. Finally, a new microcircuit silver conductor composition was described, which has excellent solderability and aged adhesion performance.

\section{REFERENCES}

1. W. A. Crossland and L. Hailes, "Thick Film Conductor Adhesion Reliability," Proceedings of International Society of Hybrid Micro-electronics, pp. 3.3.1-3.3.13 (November 1970).

2. R. G. Loasby, N. Davey, and H. Barlow, "Enhanced Property Thick Film Conductor Pastes," Solid State Technology, p. 46 (May 1972).

3. G. J. Ewell, "Adhesion Degradation of Soldered Thick Film Chip Resistors During Elevated Temperature Exposure," Proceedings of Electronic Components Conference, pp. 168-171 (1978).

4. A. A. Milgram, "Influence of Metallic Diffusion on the Adhesion of Screen Printed Silver Films," Metallurgical Transactions, 1, pp. 695-699 (March 1970).

5. A. Der Marderosian, "The Electrochemical Migration of Metals," Proc. ISHM, p. 134 (1979).

6. J. R. Larry and R. B. Amin, "High Adhesion, Thick Film Palladium-Silver Conductors," Proceedings EEC, pp. 161-170 (1972). 

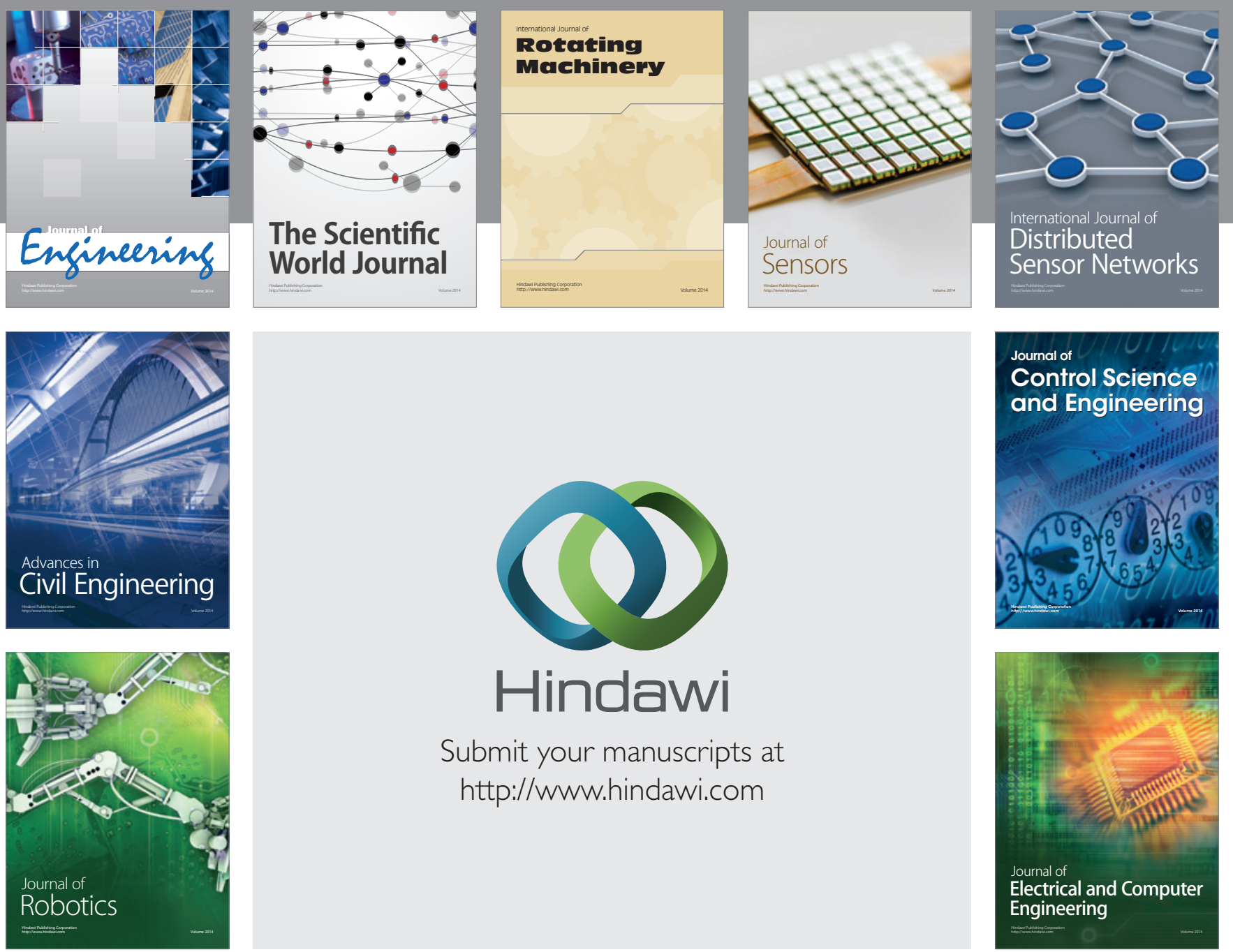

Submit your manuscripts at

http://www.hindawi.com
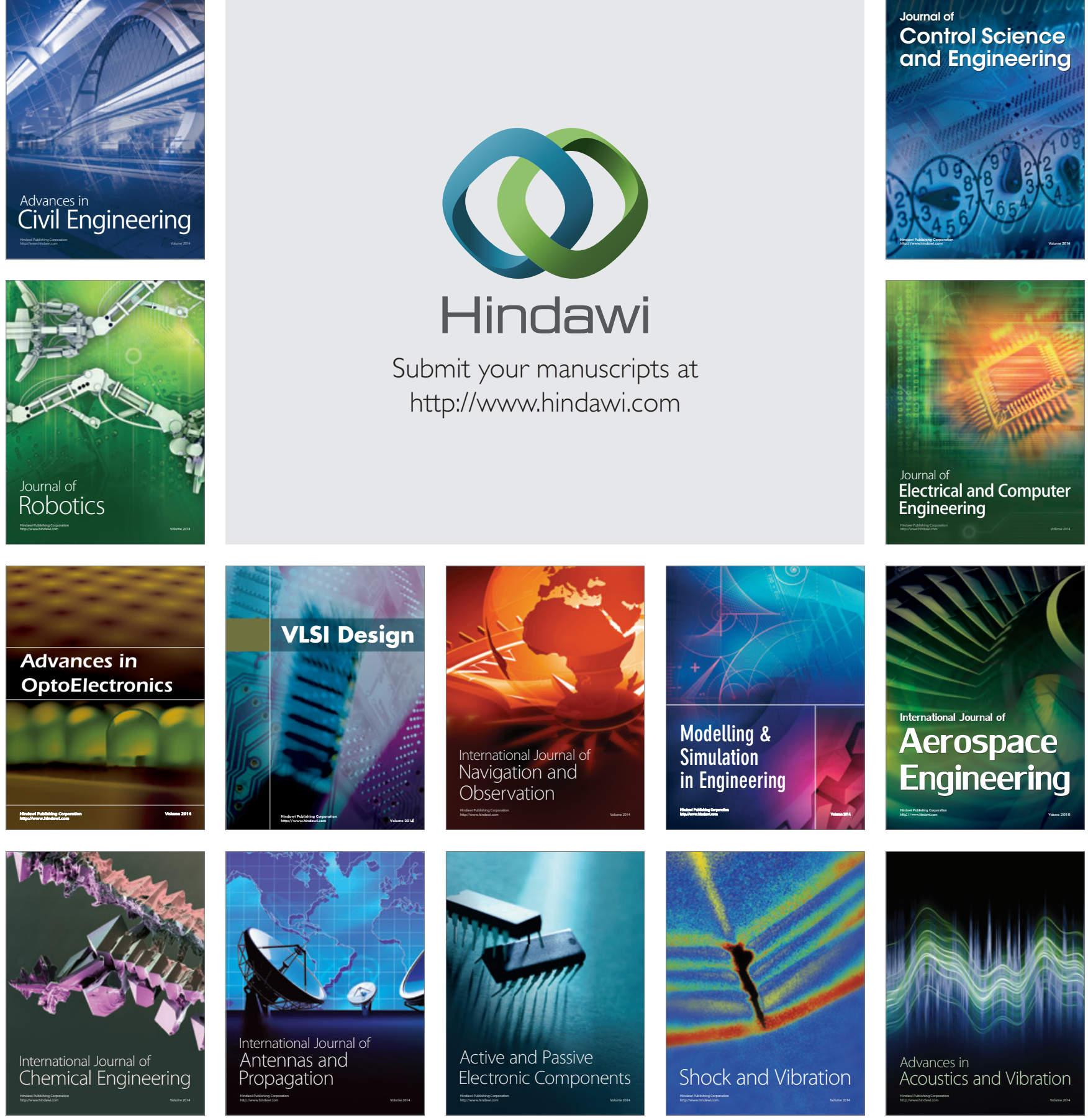